\title{
Toward the reconstruction of Proto-Na-Dene
}

\begin{abstract}
The paper presents the author's current version of the reconstruction of the phonological system of Proto-Na-Dene (PND = Proto-Athabaskan-Eyak-Tlingit in J. Leer's terms), based on comparison of three groups of languages: 1) Tlingit dialects, 2) Eyak and 3) Athabaskan languages (Proto-Athabaskan). Eyak and the Athabaskan languages are quite close to each other and are traced back to an intermediate Proto-Eyak-Athabaskan language. Regular phonetic correspondences between Eyak and PA have received an original interpretation by Michael E. Krauss and Jeffrey Leer, including very complicated correspondences of sonorants. In his works, J. Leer proposed a PND reconstruction that explained most of the regular sound correspondences between the Na-Dene languages. Although Leer's reconstruction is quite seductive with its apparent simplicity, in some aspects this simplification is unwarranted, as the real situation turns out to be a lot more complicated. This is possibly a consequence of the number of the roots involved: Leer's reconstruction is based on a relatively short list of cognate sets (ca. 300), whereas the author of the current paper has tried to take into account the entire comparative corpus (ca. 800 sets). Due to volume restrictions, the paper consists of only a brief summary of the reconstruction and an illustrative subset of the comparative material, dealing with certain complicated sound correspondences between front and lateral affricates/fricatives, previously analysed in a different light by J. Leer.
\end{abstract}

Keywords: Na-Dene languages, Athabaskan languages, historical phonology.

Reconstruction of Proto-Na-Dene (= Proto-Athabaskan-Eyak-Tlingit, PAET in Jeff Leer's terms) is based on comparison of three groups of languages: 1) Tlingit dialects (Tl), 2) Eyak (E) and 3) Athabaskan languages $(\mathrm{PA}=\text { Proto-Athabaskan })^{1}$. Eyak and the Athabaskan languages are close to each other and are traced back to an intermediate Proto-Eyak-Athabakan language $(\mathrm{PEA}=\mathrm{PAE}$ of Jeff Leer). The regular phonetic correspondences between Eyak and PA were interpreted by Michael E. Krauss and Jeffrey Leer, including very complicated correspondences of sonorants (Krauss \& Leer 1981). Leer (1992; 2008; 2008a) has proposed a PND reconstruction, explaining most of the regular sound correspondences between the Na-Dene languages. Leer's reconstruction is quite seductive with its apparent simplicity, but in some aspects this simplification is unwarranted, as the real situation turns out to be a lot more complicated.

Volume restrictions permit me little more than a brief digest of the Proto-Na-Dene reconstruction; the material listed below deals only with certain complicated sound correspondences of front and lateral affricates/fricatives that have been, in general, previously analysed by Leer 2008; 2008a. ${ }^{2}$

${ }^{1}$ A close genetic relationship between Tlingit, Eyak and Athbaskan has been proven to general satisfaction (Krauss 1964, 1965, 1968, 1969; Krauss \& Leer 1981; Leer 1979, 2008, 2008a). The affiliation of Haida with the NaDene family remains rather speculative. John Enrico has presented an annotated list of presumable cognates (Enrico 2004), for the most part consisting of early Athabaskan (or even Eyak-Athabaskan) borrowings. This means that Haida data may at least be of additional help with the Eyak-Athabaskan reconstruction.

${ }_{2}^{2}$ My Na-Dene data base, available online at http://starling.rinet.ru, contains a collection of relevant data (PND and PA reconstructions; external comparison; detailed comments and references). The main sources of my 
The Proto-Athabaskan forms in this paper are generally established on the basis of the "regional" protoforms in Leer 1996. Positional alternations of voiced and voiceless fricatives have been unified: ${ }^{*} \mathrm{~S}={ }^{*} \mathrm{~S} /{ }^{*} \mathrm{Z}$. The secondary clusters of the ${ }^{*} \mathrm{~S}$ type are presented as ${ }^{*} \mathrm{C} .{ }^{*} \mathrm{~N}=$ ${ }^{*} \mathrm{n} \sim{ }^{*} \mathrm{n} \sim{ }^{*} \mathrm{~m}$. Krauss and Leer's PA final glottalized sonorants $\left(R^{\prime}\right)$ are presented as $R$ ? PA orinasal and glottalized ("constricted") long vowels are transliterated as a vowel plus $N / 2:{ }^{*} \mathrm{~V}: \mathrm{N}$

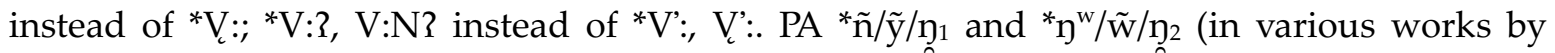
Krauss and Leer) are replaced with ${ }^{*}$ ń, ${ }^{*} \mathrm{~m}$ respectively.

The sign " $~$ " in PND and PA reconstructions denotes alternative rather than alternating variants. Etymological variants are divided with a comma.

In the Proto-Na-Dene forms: root-medial $E={ }^{*} \mathrm{i} \sim{ }^{*}$ ä; root-final $E={ }^{*} \mathrm{i} \sim{ }^{*}$; ; root-medial $A=$ *a $\sim$ *.

Tlingit forms in Leer 1975 contain information on Pre-Tlingit prosody: three phonations on long vowels. In my notation: $h$ - fading phonation; $?$ - clipped phonation; “:” - sustained phonation ${ }^{3}$; “;” - Pre-Tlingit phonation may have been sustained or glottalized; [?] - PreTlingit phonation is not determined.

\section{Vowel correspondences}

Straightforward comparison of Tlingit vowels with Eyak and Athabaskan generates an enormous number of non-interpretable series. Comparison of the PEA reconstruction with Tlingit is not more informative: any PEA vowel can correspond to any vowel in Tlingit, because any Eyak vowel can correspond to any Athabaskan vowel (except for the CV-type roots, where correspondences are trivial). Only comparison of Tlingit and Eyak gives a reasonable system. Provisionally, for PND roots I reconstruct final vowels that are almost completely lost in descendant languages, but may have left traces in the coloring of PA vowels.

I assume that PND roots had a basic shape of $\mathrm{CV}$ or $(\mathrm{CV}) \mathrm{CV}(\mathrm{C}) \mathrm{CV}$ (there was possibly a CVC structure, but there is no way to distinguish it from $\mathrm{CVCV}$ ). In most contemporary NaDene languages stress is placed on the first root vowel; unstressed vowels are reduced up to complete deletion. Secondary voiced fricatives and glottalized consonants are reconstructed in PA not only between vowels, but also in root-final position; this supposes an original intervocalic position. Many PA noun roots end in * ${ }^{*}$ which probably reflects PND root-final vowels,

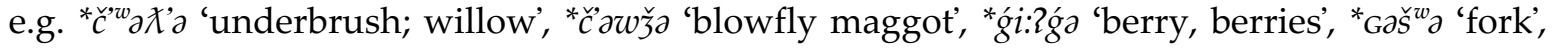
*tu:q’a 'fish, salmon', *še:na 'summer, *t'a:q’a 'three', *təńa 'path, trail', "toza 'night', “t'e:da 'teenage girl', 'xaya 'winter' (Krauss 1979; Krauss \& Leer 1981). Root-final vowels are admittedly preserved before suffixes in Tlingit, Eyak and PA; because of this, many suffixes have a secondary shape of VC. However, it is hard to directly reconstruct the quality of root-final vowels, since they are usually represented by a neutral sound. In PA suffixes with the structure VS a unified * $a$ is reconstructed. But in some Athabaskan languages reflexes of the "subordinate $a$ " differ from reflexes of the "root $a$ ". This may be a generalizing of different root-final vowels in the

reconstruction are: Tlingit: default source is Leer 1975 (a morphophonological representation of Tlingit wordforms with a reconstruction of phonations). Abbreviations: ITl = Inner Tlingit; NTl = Northern Tlingit; Yak = Yakutat; Tg = Tongass. Additional sources on NTl: Gillian L. Story, Constance M. Naish. Tlingit verb dictionary. Fairbanks, 1973; Constance Naish, Gillian Story. English-Tlingit dictionary. Nouns. Fairbanks, 1963; Keri Edwards. Dictionary of Tlingit. Juneau, 2009. Eyak: Krauss 1970. Proto-Athabaskan: default source is Leer 1996. My additional reconstructions are based on the data of Athabaskan dictionaries.

${ }^{3}$ The same notation of these phonations is used for Eyak. 
history of separate languages. Eyak possibly preserves ancient root-final vowels in semantically "empty" nominal suffixes - eh, - uh, -ah. The Tlingit and Eyak roots (except for CV) consistently end in consonants; therefore, I rely on Proto-Athabaskan, where preserved final vowels could cause Umlaut on the root-medial vowel.

Three PND root-final vowels are reconstructed, assuming assimilation of the PA root-medial vowels to three root-final vowels $\left({ }^{*} i,{ }^{*}\right.$, $\left.{ }^{*} a\right)$. The PND medial vowels are freely combined with any of the final ones.

My reconstruction of vowels is shown in Table 1.

Table 1. Vowel correspondences and PND reconstruction.

\begin{tabular}{|c|c|c|c|c|c|c|}
\hline \multirow[b]{2}{*}{ PND } & \multirow[b]{2}{*}{ Tlingit } & \multirow[b]{2}{*}{ Eyak } & \multicolumn{4}{|c|}{ Proto-Athabaskan } \\
\hline & & & $\begin{array}{l}\text { in mono- } \\
\text { syllables }\end{array}$ & before ${ }^{*}-\mathrm{i}$ & before ${ }^{*}$-ə & before ${ }^{*}$-a \\
\hline$*_{i}$ & i, e $(u)^{4}$ & i, e (u) / ə (u) & e: (u:) / ə (u) & i: (u:) / ə (u) & e: / ə (u) & $\mathrm{a}: / \mathrm{a}^{5}$ \\
\hline *ä & $\mathrm{i}, \mathrm{e}(\mathrm{u})$ & $\mathrm{a} / \mathrm{\partial}$ & a: / a & i: (u:) / ə (u) & e: / ə (u) & a: / a \\
\hline *ə & a & i, e (u) / ə (u) & e: (u:) / ə (u) & i: (u:) / ә (u) & e: / ə (u) & $\mathrm{a}: / \mathrm{a}$ \\
\hline$* a$ & a & a / ə & $\mathrm{a}: / \mathrm{a}$ & i: (u:) / ə (u) & $\mathrm{e}: / \partial(\mathrm{u})$ & $\mathrm{a}: / \mathrm{a}$ \\
\hline
\end{tabular}

Tlingit i/e may reflect two different "Pre-Tlingit" phonemes, but the distribution of these vowels in dialects seems to be chaotic. A dialectal (?) development $a(:)>e(:)$ in some roots remains unexplored. Historical distribution of i/e in Eyak is also unclear, contrary to Leer's opinion.

The correspondence $\mathrm{Tl} i / e-\mathrm{E} a$ is considered by Leer as a manifestation of qualitative ablaut. But there are almost no traces of such an ablaut in separate groups, in contrast to the quantitative one (Krauss \& Leer 1981: 78-93), and there is no reason to explain a trivial vowel correspondence with its help.

There are no grounds for the reconstruction of PND rounded vowels. The vowel $u$ does not form an independent series of correspondences. Leer's series ${ }^{*} 0(\mathrm{Tl} u-\mathrm{E} a)$ is a particular case of development of PND * $\ddot{a}(\mathrm{Tl} i / e-\mathrm{E} a)$. The correspondence “Tl, E, PA $u$ " (Leer's PND ${ }^{*} u$ ) is too scarce: usually $u$ is observed in one or two languages, when the other(s) has (have) an unrounded vowel. Thus, the $u(:)$ is not original in any of the groups, being a result of assimilation to adjacent labialized and labial consonants, including a hypothetical sequence ${ }^{*} \mathrm{CVwCV}$. Vowels turn into an $u(:)$ independently in all three groups, but the details of this process remain unstudied. Labialization of obstruents often disappears before $[e(:)]$ in Tlingit and is preserved more often before $[a(:)]$. Variants such as $i K^{w} /\left[u K^{w}\right], K^{w i} i /\left[K^{w} u\right]^{6}$ fluctuate from one Tlingit dialect to another. Tlingit also has a regular reflex ${ }^{*} w i>w u^{7}$. A labialization process in history of Eyak and Athabaskan was apparently similar to the one in Tlingit. It is important to note that there is no vowel labialization in the vicinity of PND sibilants and lateral affricates / fricatives either in Tlingit or in Eyak-Athabaskan, unless they develop into labialized palatal/velar consonants - this fact may determine relative chronological frames of vowel labialization.

Cf. Leer's reconstruction in Table 2 (according to Leer 2008a: 173 in my transliteration).

4 The slash mark separates reduced variants from full ones; labialized variants of vowels are given in brackets.

${ }^{5}$ Reflexes of PA * $a$ are unstable in many Athabaskan languages and are often replaced with reflexes of *a.

Therefore, a PA reconstruction of * $\Rightarrow$ is often encountered in the place of * $a$ because of insufficient data.

${ }^{6}$ Velar and uvular consonants in Tlingit automatically receive labialization before and after the $u$.

7 The shift $a K^{w}>u K^{w}, w a>w u$ is strictly dialectal. 
Table 2. Vowel correspondences and PAET reconstruction by Leer.

\begin{tabular}{|c|c|c|c|c|}
\hline PAET & Tlingit & PAE & Eyak & PA \\
\hline$*_{\mathrm{i}} \mathrm{i}(:)$ & $\mathrm{i}$ & $* \mathrm{i}(:)$ & $\mathrm{i}(:)$, ә & ${ }^{*} \mathrm{i}(:),{ }^{*} \partial$ \\
\hline $\begin{array}{l}{ }^{*} \mathrm{i}(:) \text { next to rounded } \\
\text { consonant }\end{array}$ & $\mathrm{u}$ & *e(:) & $\mathrm{e}(:)$, ә & *e:, *ə \\
\hline * $\mathrm{i}($ :) next to uvular & $\mathrm{i} \sim \mathrm{e}$ & *e(:) & $\mathrm{e}(:)$, ә & *e:, *ə \\
\hline *e(:) & a & *e(:) & $\mathrm{e}(:), \partial$ & *e:, *ə \\
\hline *a(:) & a & *a(:) & $\mathrm{a}(:), \partial$ & *a:, *a \\
\hline *o(:) & $\mathrm{u}$ & $* a(:)$ & $\mathrm{a}(:)$, ә & *a:, *a \\
\hline${ }^{*} \mathrm{u}(:)$ & $\mathrm{u}$ & ${ }^{*} \mathrm{u}(:)$ & $\mathrm{u}(:), \partial$ & ${ }^{*} \mathrm{u}:{ }^{*} \mathrm{u}$ \\
\hline
\end{tabular}

I omit here any reconstruction of PND prosody - vowel quantity, tones and/or phonations. Tlingit and Eyak are very similar in respect to this: short/long (or full/reduced) vowels and three phonations (clipped, fading and sustained) in long vowels are symmetric with three laryngeal features of occlusives: clipped $\approx$ glottalized, fading $\approx$ aspirated and sustained $\approx$ neutral. This system is preserved in Eyak and in some Tlingit dialects. These phonations turn into tones in Tlingit dialects: clipped phonation turns into rising tone; fading phonation into falling tone; sustained phonation turns into one of the tones depending on dialect. Proto-Athabaskan had short/long vowels and clipped/neutral phonations in vowels of either quantity. In Athabaskan languages clipped phonation turns into rising tone and sustained phonation into falling tone (in "highmarked" languages), or vice versa (in "low-marked" languages). There is no evidence of any interaction between phonations and laryngeal features of obstruents in Tlingit and Eyak. In Athabaskan * $-\mathrm{V}(:) \mathrm{C}^{\prime}>{ }^{*}-\mathrm{V}(:) 3 \mathrm{~S}$ before consonants and in word-final position; a glottal stop precedes glottalized obstruents after short vowels and arises before the so called glottalized sonorants (clusters $R 2$ in my notation ${ }^{8}$ ) and more or less functions as a segmental phoneme. In other words, the Eyak-Athabaskan clipped phonation was no more than an ordinary word-medial / final *2 after vowels and sonorants. But for the time being, a straightforward comparison of the Tlingit and Eyak-Athabaskan phonations gives no basis for a reliable PND reconstruction.

\section{Sonorant correspondences}

A velar sonorant $/ Y$ / has presumably recently gone extinct in Tlingit; this was a consonant distinct from $/ y /$ at least in root-initial position. Nowadays they differ only on the morphophonological level: ${ }^{*} Y>\{Y\}$ (represented as positional alternation between $y$ and $w$ ), ${ }^{*} y->\{y$ - $\}$ (non-alternating $y$-). There are examples of secondary development ${ }^{*} y->\{Y-\}$ in several Tlingit dialects.

My reconstruction of sonorants is shown in Table 3.

The clusters ${ }^{*} \mathrm{nC},{ }^{*} \mathrm{mC}$ keep their nasalization in Eyak and/or Athabaskan, but ${ }^{*} \mathrm{NC}>\mathrm{C}$ in Tlingit (except for NC $<{ }^{*} \mathrm{NVC}$ ). Rules of preservation/loss of nasals in NC-clusters both on the Eyak and the Athabaskan side remain to be ascertained. Since PEA nasal sonorants go back not only to $\mathrm{PND}{ }^{*} n,{ }^{*} m$, but also to PND ${ }^{*} l,{ }^{*} \eta$, and ${ }^{*} \eta{ }^{w}$, reconstruction of PND ${ }^{*} n C$ is theoretically equal to ${ }^{*} l C \sim{ }^{*} n C \sim{ }^{*} \eta C$ and reconstruction of ${ }^{*} m C$ is equal to ${ }^{*} m C \sim{ }^{*} \eta{ }^{w} C$. PND ${ }^{*} m C$ is re-

${ }^{8}$ These PA units could be reconstructed as PND glottalized sonorants if they had consistent parallels in Tlingit. In this case Eyak initial clusters $2 l-, ? n, ? y-, 2 w$ - would be worth interpreting as reflexes of PND *'”-, * $n$ '- etc. 
Table 3. Sonorant correspondences and PND reconstruction.

\begin{tabular}{l|l|l|l}
\hline \multicolumn{1}{c|}{ PND } & \multicolumn{1}{c|}{ Tlingit } & \multicolumn{1}{c}{ Eyak $^{9}$} & \multicolumn{1}{c}{ PA } \\
\hline${ }^{*} \mathrm{l}$ & $\mathrm{Y}-, \mathrm{Y} / 0^{10}$ & $\mathrm{l},-\mathrm{V}$ & ${ }^{*} \mathrm{n}-, \mathrm{n}(/ 0)$ \\
\hline${ }^{*} \mathrm{~m}$ & $\mathrm{n}$ & $\mathrm{w}-, 0$ & ${ }^{*} \mathrm{~m}$ \\
\hline${ }^{*} \mathrm{n}$ & $\mathrm{n}$ & $\mathrm{n} / \mathrm{l},-\mathrm{V}$ & ${ }^{*} \mathrm{n}$ \\
\hline${ }^{*} \mathrm{n}$ & $\mathrm{r}-, \mathrm{n}$ & $2,-\mathrm{V}$ & ${ }^{*} \mathrm{n}$ \\
\hline${ }^{*} \mathrm{n}$ & $\mathrm{Y}-, \mathrm{Y} / 0$ & $2-, 0$ & ${ }^{*} \mathrm{n}$ \\
\hline${ }^{*} \mathrm{y}^{\mathrm{w}}$ & $\mathrm{Y}-, \mathrm{Y} / 0$ & $\mathrm{w}-, 0$ & ${ }^{*} \mathrm{~m}$ \\
\hline${ }^{*} \mathrm{w}$ & $\mathrm{w}-, 0 / \mathrm{w}$ & $\mathrm{w}-, 0 / \mathrm{w}$ & ${ }^{*} \mathrm{w}-, \mathrm{w} / 0$ \\
\hline${ }^{*} \mathrm{y}$ & $\mathrm{y}-/ \mathrm{Y}-, 0 / \mathrm{Y}$ & $\mathrm{y}-, 0$ & ${ }^{*} \mathrm{y}-, \mathrm{y} / 0$ \\
\hline
\end{tabular}

Table 4. Sonorant correspondences and PAET reconstruction by Leer.

\begin{tabular}{l|l|l|l|l}
\hline \multicolumn{1}{c|}{ PAET } & Tlingit & \multicolumn{1}{c|}{ PAE } & \multicolumn{1}{c}{ Eyak } & \multicolumn{1}{c}{ PA } \\
\hline${ }^{*} \mathrm{n}$ & $\mathrm{Y}$ & ${ }^{*} \mathrm{n}$ & $\mathrm{y}$ & ${ }^{*} \mathrm{n}$ \\
\hline${ }^{*} \mathrm{n}$ & $\mathrm{n}$ & ${ }^{*} \mathrm{n}$ & $1 \sim \mathrm{n}$ & ${ }^{*} \mathrm{n}$ \\
\hline${ }^{*} \mathrm{n}$ & $\mathrm{Y}$ & ${ }^{*} \mathrm{n}$ & $1 \sim \mathrm{n}$ & ${ }^{*} \mathrm{n}$ \\
\hline${ }^{*} \mathrm{n}^{\mathrm{w}}$ & $\mathrm{w}$ & ${ }^{*} \mathrm{n}$ & 1 & ${ }^{*} \mathrm{n}$ \\
\hline${ }^{*} \mathrm{y}$ & $\mathrm{Y}$ & ${ }^{*} \mathrm{y}$ & $\mathrm{y}$ & ${ }^{*} \mathrm{y}\left(\sim^{*} \mathrm{n}\right)$ \\
\hline${ }^{*} \mathrm{w}$ & $\mathrm{w}, \mathrm{Y}$ & ${ }^{*} \mathrm{~W}$ & $\mathrm{w}$ & ${ }^{*} \mathrm{w}$ \\
\hline
\end{tabular}

constructed whenever 1$){ }^{*} m$ labializes the preceding vowel; 2) there is a development "early PA" ${ }^{*} \mathrm{Ci}(:) m C>\mathrm{PA}{ }^{*} \mathrm{Cu}: n c$ ( ${ }^{*} \mathrm{Cu}: \mathrm{C}$ in Leer's notation). Elsewhere I reconstruct PND root-medial clusters like $w N, y N$ in a few roots where non-trivial sound correspondences force me to do so. Despite the fact that the sound correspondences are generally established, defining the quality of medial-root sonorants is often difficult, unless they have evident reflexes (such as $-n$ - in all the subgroups). Many PND roots reconstructed as ${ }^{*} C V$ may have really had a more complicated structure, i.e. ${ }^{*} \mathrm{CVy} V,{ }^{*} \mathrm{CVw} V,{ }^{*} \mathrm{CV} 2\left({ }^{w}\right) V,{ }^{*} \mathrm{C} V h\left({ }^{w}\right) V$. Truly monosyllabic nominal roots often show metathesis in Tlingit: $\{u h \chi$ (cf. PA * $\chi u$ : 'tooth'); ih $\chi$ 'oil', cf. PA * $\chi$ e: 'grease, oil, tallow', etc. Sometimes a former bisyllabic structure may be guessed on the basis of irregular vowel correspondences. But reconstruction of all remaining "monosyllabic" roots as * $\mathrm{CVHV}[\mathrm{H}=$ $y, w, h\left({ }^{w}\right), z\left(^{w}\right)$ ] seems supefluous. Cf. Leer's sonorant reconstruction in Table 4 (according to Leer 2008a: 172 in my transliteration).

\section{Obstruent correspondences}

My interpretation of sound correspondences is presented in Table 5. A transcription is accepted for the Na-Dene languages, in which "voiced" letters denote non-aspirated voiceless or

${ }^{9}$ Eyak has complicated reflexes of sonorants in intervocalic position. In particular, hiatus (when a sonorant is deleted) is eliminated by means of $-y-/-w-/-2$ - depending on preceding vowels; $-n->-m$ - after certain labializing segments. Note also that PND * $w V N(C)>\mathrm{E} m V(C)>m V(c)$ (Krauss \& Leer 1981).

${ }^{10}$ Here and further in the tables initial, medial and final reflexes are shown for roots rather than wordforms (where root-initial reflexes can be found in medial position). 
Table 5. Obstruent correspondences and PND reconstruction.

\begin{tabular}{|c|c|c|c|c|}
\hline PND & Tlingit & Eyak & PA & $\begin{array}{c}\text { Statistics } \\
\text { (initial/ medial) }\end{array}$ \\
\hline$* \mathrm{~d}$ & $\mathrm{t}-/ \mathrm{d}-, \mathrm{d}$ & d & ${ }^{*} \mathrm{~d}$ & $52^{11 / 30}$ \\
\hline${ }^{*} \mathrm{t}-$ & $t-/ d-$ & $\mathrm{t}-$ & ${ }^{*} \mathrm{t}-$ & 41 \\
\hline${ }^{*} \mathrm{t}$ & $t^{\prime}-, t^{\prime} / d$ & $\mathrm{t}^{\prime}$ & ${ }^{*} \mathrm{t}^{\prime}$ & $20 / 30$ \\
\hline$*_{3}$ & š-, 3 & 3 & $*_{3}$ & $3 / 11$ \\
\hline${ }^{*} \mathrm{C}-$ & š- & $\mathrm{c}-$ & ${ }^{*} \mathrm{C}-$ & 12 \\
\hline${ }^{*} \mathrm{C}$ & $c^{\prime}-, c^{\prime} / 3$ & $c^{\prime}$ & ${ }^{*} \mathrm{c}^{\prime}$ & $6 / 4$ \\
\hline$*^{*} \mathrm{~S}$ & s- & $\mathrm{s}$ & $*^{*} \mathrm{~s}$ & $16 / 5$ \\
\hline *s' & $\mathrm{s}^{\prime}$ & $c^{\prime}$ & ${ }^{*} \mathrm{c}^{\prime}-, \mathrm{c}^{\prime} / \mathrm{s}$ & $16 / 21$ \\
\hline $3^{* w}$ & $g\left({ }^{w}\right)$ & 3 & $* 3$ & $6 / 6$ \\
\hline${ }^{*} \mathrm{C}^{\mathrm{w}}$ & $\mathrm{k}\left({ }^{\mathrm{w}}\right)-, \mathrm{k}^{\prime}\left({ }^{\mathrm{w}}\right) / \mathrm{g}\left({ }^{\mathrm{w}}\right)$ & $c^{\prime}$ & ${ }^{*} \mathrm{C}^{\prime}$ & $3 / 3$ \\
\hline${ }^{*} \mathrm{C}^{\mathrm{w}}-$ & $\mathrm{k}\left({ }^{\mathrm{w}}\right)-/ \mathrm{g}\left({ }^{\mathrm{w}}\right)-$ & $\mathrm{c}^{-}$ & ${ }^{*} \mathrm{C}-$ & 11 \\
\hline${ }^{*} \mathrm{~s}^{\mathrm{w}}$ & $x\left({ }^{w}\right)$ & $\mathrm{s}$ & ${ }^{*} \mathrm{~s}$ & $14 / 3$ \\
\hline${ }^{*} \mathrm{~s}^{\mathrm{w}}$ & $x^{\prime}\left({ }^{w}\right)$ & $c^{\prime}$ & ${ }^{*} \mathrm{c}^{\prime}-, \mathrm{c}^{\prime} / \mathrm{s}$ & $2 / 10$ \\
\hline 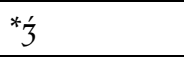 & $\mathrm{c}-/ 3-, 3$ & $\check{3}$ & $* \check{3}$ & $8 / 4$ \\
\hline *ć- & $\mathrm{c}-/ 3^{-}$ & č- & *č- & 7 \\
\hline *ć & $\mathrm{c}^{\prime}$ & č & *čc & $2 / 7$ \\
\hline *ś & $\mathrm{s}$ & š & ${ }^{* \check{S}^{w}}$ & $6 / 7$ \\
\hline \multicolumn{5}{|l|}{ 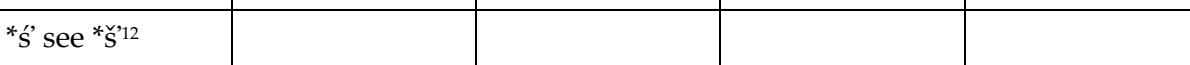 } \\
\hline${ }^{*} \dot{s}^{\mathrm{w}}(?)$ & s-/š- & $x-$ & ${ }^{*} x^{\prime}-$ & $3 /-$ \\
\hline$*^{*}$ & č- $/ \check{3}-$, & $\breve{3}(/ 3)^{13}$ & $* \check{3}$ & $11 / 12$ \\
\hline *̌c- & č- & č- & *č- & 19 \\
\hline *气̌ & $\check{c}$ & $\check{c}\left(/ c^{\prime}\right)$ & *č & $15 / 1$ \\
\hline *š & š & $\check{s}(/ \mathrm{s})$ & ${ }^{*} \check{S}^{w}$ & $19 / 19$ \\
\hline *̌̌' (and *'s?) & s' & $\check{c} \check{c}(/ c ')$ & * & $15 / 19$ \\
\hline$*^{*}{ }^{w}$ & $\mathrm{k}\left({ }^{\mathrm{w}}\right)-/ \mathrm{g}\left({ }^{\mathrm{w}}\right)-, \mathrm{g}\left({ }^{\mathrm{w}}\right)$ & $\mathrm{g}\left({ }^{w}\right)$ & $*^{*}{ }^{w}$ & $12 / 4$ \\
\hline$*^{*} \breve{c}^{w_{-}}$ & $k\left({ }^{w}\right)-$ & $k\left({ }^{w}\right)-$ & ${ }^{*} \mathrm{c}^{w_{-}}-$ & 15 \\
\hline 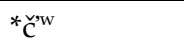 & $\mathrm{k}\left({ }^{\mathrm{w}}\right)-, \mathrm{k}^{\prime}\left({ }^{\mathrm{w}}\right) / \mathrm{k}\left({ }^{\mathrm{w}}\right)$ & $k^{\prime}\left({ }^{w}\right)-$ & $*_{\mathrm{c}} \check{\mathrm{c}}^{\prime} \mathrm{w}_{-}$ & $8 /-$ \\
\hline$*_{\mathrm{S}}{ }^{w}$ & $x\left({ }^{w}\right)-$ & $x\left(^{(w)}\right)$ & ${ }^{*{ }_{\mathrm{S}}^{\mathrm{w}}-}$ & $4 /-$ \\
\hline$*^{*}{ }^{\prime w}$ & $x^{\prime}\left({ }^{w}\right)$ & $x^{\prime}(w)$ & ${ }^{*} \widetilde{\mathrm{C}}^{\circ \mathrm{w}}-, \breve{\mathrm{c}}^{\mathrm{w}} / \breve{\mathrm{S}}^{\mathrm{w}}$ & $8 / 4$ \\
\hline${ }^{*} \mathrm{~L}$ & $\mathrm{~L}-/ X-, \mathrm{L} / \mathrm{A}$ & $\mathrm{L} / \mathrm{t}$ & ${ }^{*} \mathrm{~L} / \mathrm{t}$ & $4 / 8$ \\
\hline$* x-$ & $x-/ t-$ & $x-$ & ${ }^{*}$ X-/t- & 15 \\
\hline
\end{tabular}

${ }^{11}$ An enormous abundance of initial ${ }^{*} d$ - and ${ }^{*} t$ - can be explained by assuming the presence of the fossilized classifier $d$ - in verbal roots.

${ }^{12}$ Reflexes of presumed ${ }^{*} s$ ' and ${ }^{*}$ s do not differ from each other. In PEA, they had to merge in *č; Tlingit predictably has no $\mid \breve{s} /$, since it must have merged with $/ s$ ' at some point in Tlingit history. Thus, some parts of roots with PND *šs may indeed have had PND *s'.

${ }^{13}$ Eyak sibilants correspond to Tlingit and Athabaskan hissing sounds in a few roots and are unlikely to form an additional series. 


\begin{tabular}{|c|c|c|c|c|}
\hline PND & Tlingit & Eyak & PA & $\begin{array}{c}\text { Statistics } \\
\text { (initial/ medial) }\end{array}$ \\
\hline$* x$ & $x^{\prime}-, x^{\prime} / \mathrm{L}$ & $* x$ & $* x$ & $9 / 10$ \\
\hline${ }^{*} 1$ & $t$ & 1 & $* 1$ & $20^{14} / 34$ \\
\hline${ }^{*} \mathrm{Y}$ & Y & $x$ & $*^{*} X^{\prime}-, X ’ / 1$ & $13 / 25$ \\
\hline${ }^{*} \mathrm{~L}^{\mathrm{w}}$ & $\mathrm{L}-, \mathrm{L}(/ \mathrm{A})$ & $\mathrm{c}-, 3 / \mathrm{s}$ & ${ }^{*} \mathrm{c}-, 3 / \mathrm{s}$ & $2 / 4$ \\
\hline${ }^{*} \chi^{\mathrm{w}}-$ & $x-$ & c- & ${ }^{*} \mathrm{C}-$ & 8 \\
\hline${ }^{*} \chi^{\prime w}$ & $x^{\prime}$ & $\mathrm{c}^{\prime}$ & ${ }^{*} \mathrm{C}^{\prime}$ & $5 / 4$ \\
\hline$* 1^{w}$ & 1 & $\mathrm{~s}$ & ${ }^{*} \mathrm{~s}$ & $8 / 5$ \\
\hline${ }^{*} \mathrm{Y}^{\mathrm{w}}$ & l' & $c^{\prime}$ & ${ }^{*} \mathrm{C}^{\prime}-, \mathrm{s}^{\prime} / \mathrm{s}$ & $5 / 5$ \\
\hline$* g$ & $\mathrm{k}-/ \mathrm{g}-, \mathrm{g}$ & $\mathrm{g}$ & *'ǵ & $14 / 10$ \\
\hline${ }^{*} \mathrm{k}-$ & $\mathrm{k}-/ \mathrm{g}-$ & $\mathrm{k}-$ & ${ }^{*} \mathrm{k}-$ & 14 \\
\hline${ }^{*} \mathrm{k}$ & $k^{\prime}-, k^{\prime} / k$ & $\mathrm{k}$ & ${ }^{*} \mathrm{~K}^{\prime}$ & $4 / 6$ \\
\hline$*^{*} x$ & $x$ & $x$ & $* \dot{x}$ & $9 / 3$ \\
\hline${ }^{*} x^{\prime}$ & $x^{\prime}$ & $\mathrm{k}^{\prime}$ & ${ }^{*} \mathrm{k}^{\prime}-, \mathrm{k}^{\prime} / \mathrm{x}$ & $4 / 7$ \\
\hline${ }^{*} \mathrm{~g}^{\mathrm{w}}$ & $\mathrm{k}\left({ }^{\mathrm{w}}\right)-/ \mathrm{g}\left({ }^{\mathrm{w}}\right)-, \mathrm{g}\left({ }^{\mathrm{w}}\right)$ & $g\left({ }^{w}\right)$ & ${ }^{*} \mathrm{~g}^{\prime 15}$ & $18 / 18$ \\
\hline${ }^{*} \mathrm{k}^{\mathrm{w}}-$ & $k\left({ }^{w}\right)-/ g\left({ }^{w}\right)-$ & $k\left({ }^{w}\right)-$ & ${ }^{*} \mathrm{k}$ - & 18 \\
\hline${ }^{*} \mathrm{k}^{\mathrm{w}}$ & $\mathrm{k}^{\prime}\left({ }^{\mathrm{w}}\right)-, \mathrm{k}^{\prime}\left({ }^{\mathrm{w}}\right) / \mathrm{k}\left({ }^{\mathrm{w}}\right)$ & $\mathrm{k}^{\prime}\left({ }^{w}\right)$ & ${ }^{*} \mathrm{~K}^{\prime}-, \mathrm{k} / \mathrm{x}$ & $5 / 12$ \\
\hline${ }^{*} x^{w}$ & $x\left({ }^{w}\right)$ & $x\left({ }^{w}\right)$ & *'́x & $17 / 6$ \\
\hline${ }^{*} \mathrm{x}^{\mathrm{w}}$ & $x^{\prime}(w)$ & $\mathrm{k}^{\prime}\left({ }^{\mathrm{w}}\right)$ & ${ }^{*} \mathrm{k}$ & $7 / 12$ \\
\hline${ }^{*} \mathrm{G}$ & $\mathrm{G}-/ \mathrm{q}-, \mathrm{G}$ & G & ${ }^{*} \mathrm{G}$ & $32 / 19$ \\
\hline${ }^{*} \mathrm{q}-$ & q- & q- & ${ }^{*} \mathrm{q}-$ & 22 \\
\hline *q' & $q^{\prime}-, q^{\prime} / q$ & $\mathrm{q}^{\prime}$ & ${ }^{*} \mathrm{q}^{\prime}$ & $6 / 5$ \\
\hline${ }^{*} \chi^{16}$ & $\chi$ & $x$ & ${ }^{*} \chi$ & $15 / 13$ \\
\hline${ }^{*} \chi^{\prime}$ & $\chi^{\prime}$ & $q^{\prime}$ & ${ }^{*} \mathrm{q}^{\prime}-, \mathrm{q}^{\prime} / \chi$ & $15 / 13$ \\
\hline${ }^{*} \mathrm{G}^{\mathrm{W}}$ & $\mathrm{G}\left({ }^{\mathrm{W}}\right)$ & G & ${ }^{*} \mathrm{G}\left({ }^{\mathrm{w}}\right)$ & $7 / 8$ \\
\hline${ }^{*} \mathrm{q}^{\mathrm{w}}-$ & $q\left({ }^{w}\right)-$ & $\mathrm{q}^{-}$ & ${ }^{*} \mathrm{q}(\mathrm{w})-$ & 11 \\
\hline${ }^{*} \mathrm{q}^{\mathrm{w}} ?$ & $?$ & $q^{\prime}$ & ${ }^{*} \mathrm{q}^{\prime}\left({ }^{w}\right)$ & (PEA 1/1) \\
\hline${ }^{*} \chi^{\prime \mathrm{w}}$ & $\chi^{\prime}\left({ }^{w}\right)$ & $\mathrm{q}^{\prime}$ & ${ }^{*} \mathrm{q}^{\prime}\left({ }^{\mathrm{w}}\right)-, \mathrm{q}^{\prime}\left({ }^{\mathrm{w}}\right) / \chi\left({ }^{\mathrm{w}}\right)$ & $5 / 14$ \\
\hline${ }^{*} \chi^{w}$ & $\chi\left({ }^{\mathrm{w}}\right)$ & $x$ & ${ }^{*} \chi\left({ }^{\mathrm{w}}\right)$ & $15 / 8$ \\
\hline$* 2^{17}$ & $3-$ & $3-$ & $* 2-$ & $41 /-$ \\
\hline${ }^{*} 2^{\mathrm{w}}-18$ & $3-$ & w- & ${ }^{*} \mathrm{~W}-$ & $8 /-$ \\
\hline *h- & h- & $3-$ & *h- & $15 /-$ \\
\hline${ }^{*} \mathrm{~h}^{\mathrm{W}}-19$ & h- & w- & *h- & $11 /-$ \\
\hline
\end{tabular}

${ }^{14}$ Some verb roots with initial * $t$ - may contain the fossilized classifier $t$ -

${ }^{15}$ Original labialization is reflected as a change ${ }^{*} i,{ }^{*} a>$ PA * $u(:)$.

${ }^{16} \mathrm{PND}{ }^{*} \chi,{ }^{*} \chi^{w}>\mathrm{Tl} h / 0$ before a consonant in clusters.

${ }^{17}$ Reflexes of root-medial ${ }^{*},{ }^{*}{ }^{w},{ }^{*} h,{ }^{*} h^{w}$ do not allow any reliable reconstruction, as they have been obscured by clipped and fading phonations.

${ }^{18}$ Since there is no separate PND ${ }^{*} q^{w}$ - with uvular reflexes, this correspondence may also be interpreted as reflecting PND ${ }^{*} q^{w}{ }^{w}$.

19 This correspondence can also be interpreted as PND *f-. 
Table 6. Obstruent correspondences and PAET reconstruction by Leer.

\begin{tabular}{|c|c|c|c|c|}
\hline PAET & Tlingit & PAE & Eyak & $\mathrm{PA}$ \\
\hline$* d$ & $\mathrm{~d}$ & ${ }^{*} \mathrm{~d}$ & $\mathrm{~d}$ & ${ }^{*} \mathrm{~d}$ \\
\hline${ }^{*} \mathrm{t}$ & $\mathrm{t}$ & $*_{t}$ & $t$ & $*_{t}$ \\
\hline${ }^{*} \mathrm{t}^{\prime}$ & $\mathrm{t}^{\prime}$ & $*^{*} \mathrm{t}^{\prime}$ & $\mathrm{t}^{\prime}$ & $*^{*} \mathrm{t}^{\prime}$ \\
\hline${ }^{*} 1$ & 1 & $*_{1}$ & t & ${ }^{*}+\sim \lambda$ \\
\hline${ }^{*} x^{\prime}$ & ’, X’ & $* x$ & $x$ & $* x$ \\
\hline${ }^{*} \mathrm{~s}$ & $\mathrm{~s}$ & $*_{\mathrm{S}}$ & $\mathrm{s}$ & ${ }^{*} \mathrm{~s} \quad{ }^{*} \mathrm{Z}$ \\
\hline${ }^{*} \mathrm{C}$ & c & ${ }^{*} \mathrm{C}$ & c & ${ }^{*} \mathrm{C}$ \\
\hline${ }^{*} \mathrm{c}$ & $\mathrm{s}^{\prime}, \mathrm{c}^{\prime}$ & ${ }^{*} c^{\prime}$ & $\mathrm{c}^{\prime}$ & ${ }^{*} \mathrm{c}^{\prime}$ \\
\hline “š & š (s) & * & š (s) & ${ }^{* \check{S}^{W}} \sim{ }^{*} \check{Z}^{W}$ \\
\hline *̌ & $\check{3}$ & $* \check{3}$ & $\check{3}$ & $* \check{3}$ \\
\hline *̌c & č (c) & *̌c & č & *̌c \\
\hline$* \breve{c}$ & $s^{\prime}, \check{c ̌ c}^{\prime}\left(c^{\prime}\right)$ & $*_{\mathrm{c}}$ & $\check{c}$ & $*{ }_{\mathrm{c}}^{\prime \prime}$ \\
\hline$* \dot{x}$ & $x$ & $*_{S}$ & $\mathrm{~s} ; \check{s}$ & $\mathrm{~s} \sim \mathrm{z}$ \\
\hline *ǵ & g & $*_{3}$ & 3 & ${ }^{*} 3,{ }^{*} \mathrm{~s} \sim{ }^{*} \mathrm{z}$ \\
\hline *ḱk & k; š & ${ }^{*} \mathrm{C}$ & c & $*_{\mathrm{C}}$ \\
\hline *'k' & $\mathrm{k}^{\prime}$ & ${ }^{*} \mathrm{C}^{\prime}$ & $c^{\prime}$ & ${ }^{*} \mathrm{c}^{\prime}$ \\
\hline${ }^{*} \mathrm{x}$ & $x\left({ }^{w}\right)$ & ${ }^{*} x$ & $x$ & ${ }^{*} \dot{x} \sim{ }^{*} y$ \\
\hline$* \mathrm{~g}$ & $g\left({ }^{w}\right)$ & ${ }^{*} \mathrm{~g}$ & $\mathrm{~g}$ & *ǵ \\
\hline${ }^{*} \mathrm{k}$ & $k\left({ }^{w}\right)$ & ${ }^{*} \mathrm{k}$ & $\mathrm{k}$ & $*{ }^{\prime} \mathrm{k}$ \\
\hline${ }^{*} \mathrm{k}$ & $\mathrm{x}^{\prime}\left({ }^{\mathrm{w}}\right), \mathrm{k}^{\prime}\left({ }^{\mathrm{w}}\right)$ & ${ }^{*} \mathrm{k}$ & $\mathrm{k}^{\prime}$ & ${ }^{*} \mathrm{k}^{\prime}$ \\
\hline${ }^{*} x^{w}$ & $x\left({ }^{w}\right)$ & ${ }^{*} \mathrm{x}^{\mathrm{w}}$ & $/ \mathrm{x}^{\mathrm{w}} />\mathrm{x}$ & ${ }^{*} \check{\mathrm{S}}^{\mathrm{W}} \sim{ }^{*} \check{\mathrm{Z}}^{\mathrm{W}}$ \\
\hline${ }^{*} \mathrm{~g}^{\mathrm{w}}$ & $g\left({ }^{w}\right)$ & ${ }^{*} \mathrm{~g}^{\mathrm{w}}$ & $/ \mathrm{g}^{\mathrm{w}} />\mathrm{g}$ & ${ }^{*} \check{3}^{w}$ \\
\hline${ }^{*} k^{w}$ & $\mathrm{k}\left({ }^{\mathrm{w}}\right)$ & ${ }^{*} \mathrm{k}^{\mathrm{w}}$ & $/ \mathrm{k}^{\mathrm{w}} />\mathrm{k}$ & ${ }^{*} \check{c}^{\prime w}$ \\
\hline${ }^{*} \mathrm{k}^{\mathrm{w}}$ & $\mathrm{x}^{\prime}\left({ }^{\mathrm{w}}\right), \mathrm{k}^{\prime}\left({ }^{\mathrm{w}}\right)$ & ${ }^{*} \mathrm{k}^{\mathrm{w}}$ & $/ \mathrm{k}^{\mathrm{w}} />\mathrm{k}^{\prime}$ & $*_{\mathrm{C}^{w}}^{\mathrm{w}}$ \\
\hline${ }^{*} \chi$ & $\chi\left({ }^{w}\right)$ & ${ }^{*} \chi$ & $x$ & ${ }^{*} \chi \sim{ }^{*} \mathrm{~B}$ \\
\hline${ }^{*} \mathrm{G}$ & $G\left({ }^{w}\right)$ & ${ }^{*} \mathrm{G}$ & G & ${ }^{*} \mathrm{G}$ \\
\hline${ }^{*} \mathrm{q}$ & $\mathrm{q}\left({ }^{(w}\right)$ & ${ }^{*} \mathrm{q}$ & q & ${ }^{*} \mathrm{q}$ \\
\hline *q' & $\chi^{\prime}\left({ }^{w}\right), q^{\prime}\left({ }^{w}\right)$ & ${ }^{*} \mathrm{q}$ & q' & ${ }^{*} \mathrm{q}$ \\
\hline${ }^{*} \chi^{\mathrm{w}}$ & $\chi\left({ }^{w}\right)$ & ${ }^{*} \chi^{\mathrm{w}}$ & $x$ & ${ }^{*} / \chi^{\mathrm{w}} />^{*} \chi \sim^{*} \mathrm{~K}$ \\
\hline${ }^{*} \mathrm{G}^{\mathrm{W}}$ & $G\left({ }^{w}\right)$ & ${ }^{*} \mathrm{G}^{\mathrm{w}}$ & G & $* / \mathrm{G}^{\mathrm{w}} />{ }^{*} \mathrm{G}$ \\
\hline${ }^{*} \mathrm{q}^{\mathrm{w}}$ & $\mathrm{q}\left({ }^{(w}\right)$ & ${ }^{*} \mathrm{q}^{\mathrm{w}}$ & q & $* / \mathrm{q}^{\mathrm{w}} />{ }^{*} \mathrm{q}$ \\
\hline${ }^{*} \mathrm{q}^{\prime w}$ & $\chi^{\prime}\left({ }^{w}\right), q^{\prime}\left({ }^{w}\right)$ & ${ }^{*} \mathrm{q}^{\mathrm{w}}$ & $q^{\prime}$ & ${ }^{*} / \mathrm{q}^{\prime \mathrm{w}} />^{*} \mathrm{q}^{\prime}$ \\
\hline$* ?$ & 3 & $* 2$ & $?$ & $* ?$ \\
\hline${ }^{*} \mathrm{~h}$ & $\mathrm{~h}$ & ${ }^{*}(\mathrm{~h})$ & 0 & $*(\mathrm{~h})$ \\
\hline${ }^{*} ? w$ & 3 & ${ }^{*} ?^{\mathrm{w}}$ & $\mathrm{w}$ & $?$ \\
\hline *hw & $\mathrm{h}$ & ${ }^{*} \mathrm{~W}$ & $\mathrm{w}$ & ${ }^{*} \mathrm{~W}$ \\
\hline${ }^{*} 2 y$ & 3 & $?$ & $?$ & ${ }^{*} \mathrm{y}$ \\
\hline
\end{tabular}


voiced occlusives ${ }^{20}(\mathrm{D}=[\mathrm{T}]$ or $[\mathrm{D}])$, whereas "voiceless" letters denote voiceless aspirated occlusives $\left(\mathrm{T}=\left[\mathrm{T}^{\mathrm{h}}\right]\right)$. The same orphographical principle is used in reconstructions, especially because we do not know whether the non-aspirated occlusives were voiced or voiceless. PND aspirated occlusives were present only in root-initial position along with non-aspirated and glottalized occlusives; in root-medial position only non-aspirated and glottalized occlusives were opposed ${ }^{21}$.

The Tlingit root-initial non-aspirated $(D)$ or aspirated $(T)$ reflexes of occlusives and affricates alternate even within the same dialect (e.g. NTl túqt' dúqt' 'young spruce or hemlock'). This dialectal fluctuation is accounted for by postulating a positional distribution of allophones [T] in word-initial position, [D] in intervocalic position and, subsequently, their random phonological redistribution. As a result, Tlingit almost completely lost the historical distinction between aspirated and non-aspirated occlusives. Fortunately, the distinction between PND root-initial $D$ - and T-series remains stable in Eyak-Athabaskan.

Glottalization of PND root-medial (root-final in the contemporary languages) occlusives is often lost in Tlingit and occasionally in Eyak. PA is stable in regard to occlusives, but shows numerous examples of deglottalization of root-final fricatives. Final deglottalization, although its origins remain unknown ${ }^{22}$, will not be considered below as an irregularity. In general, it is difficult to ascertain a PND distribution of laryngeal features in roots containing two obstruents, both or even one of which is glottalized in descendant languages.

A not particularly numerous row, not included in Table 5, consists of Tl labialized velars that correspond to PEA uvulars ${ }^{23}$. I consider Eyak affricates (as well as any affricate/fricative fluctuation) in place of Tlingit and PA fricatives as irregularities. Multiple reflexes of ${ }^{*} L\left({ }^{w}\right),{ }^{*} \chi\left({ }^{w}\right)$ in all the subgroups demand further research. Cf. Leer's reconstruction in Table 6 (according to Leer 2008a: 170 in my transliteration).

My interpretation of the numerous series of front and lateral affricates/fricatives seriously differs from Leer's, except for the evident series ${ }^{*} \check{c}$ - and ${ }^{*} \chi$-. The difference between our reconstructions is due primarily to Leer's neglect of some series, which he combined, considering the multiple Tlingit reflexes to be a result of internal splitting. Maybe it is a consequence of the number of the roots involved: Leer's reconstruction is based on a relatively short list of cognate sets (ca. 300), whereas I have tried to take into account the entire comparative corpus (ca. 800).

Leer does not distinguish PND glottalized affricates from fricatives, although they are strongly opposed in most Tlingit dialects, necessarily reflecting a "Pre-Tlingit" situation, since glottalized affricates and fricatives have different reflexes if they lose their glottalization in Athabaskan.

The series ${ }^{*} \breve{C}^{w}$ - can hardly be interpreted as ${ }^{*} K^{w}{ }_{-}$, contra Leer's opinion ${ }^{24}$. The series ${ }^{*} K^{w}$ - is reconstructed by me as an independent one; it yields labialized velar reflexes both in Tlingit and Eyak-Athabaskan. The series ${ }^{*} C^{w}$ - and ${ }^{*} \breve{C}^{w}$ - are reconstructed by me on the grounds that Tlingit here has labiovelar reflexes $\left(K^{w}\right)^{25}$, which can be explained as a result of a backward

\footnotetext{
${ }^{20}$ Here and further below the term "occlusives" always denotes "occlusives and affricates", and the term "obstruents" embraces occlusives, affricates and fricatives.

${ }^{21}$ At the very least, modern languages show no traces of PND word-medial aspirates.

${ }^{22}$ A fortuitous choice of one of two alternate allomorphs may have been the cause.

${ }^{23}$ E.g., Tl gu2s' 'cloudy sky' vs. E q'ahs q'wahs, PA * $q^{\text {ww } \partial s}$ 'cloud'. This root also shows methatesis of glottalization.

${ }^{24}$ Leer's interpretation goes back to Krauss's reconstruction of PEA * ${ }^{w}$-series as * $K^{w}$ (“rounded palatals”). Krauss consistently distinguishes palatals and velars, regardless of whether they are rounded or unrounded. Leer takes a further step, transforming the PEA palatal series into a velar one in PND, but disregarding the evident rounded velars with their stable back reflexes, including Athabaskan.

${ }^{25} K^{w}>K / K^{w}$, with fluctuation of labialization, also observed in velar and uvular labialized series.
} 
shift of labialized front affricates/fricatives. Leer assumes a forward shift of labialized velars in Athabaskan $\left({ }^{*} \mathrm{~K}^{\mathrm{w}}>\breve{C}^{w} / \bar{C}\right)$, whereas I suggest a backward shift of labialized front affricates / fricatives in Eyak and Tlingit: ${ }^{*} C^{w}$ and ${ }^{*} \breve{C}^{w}>{ }^{*} \breve{C}^{w}>K^{w}$ in Tlingit; ${ }^{*} c^{w}$ lost its labialization in PEA, but ${ }^{*} \check{C}^{w}>{ }^{*}\left[\breve{C}^{w}\right]>\breve{C}^{w} / \bar{C}$ in Athabaskan; ${ }^{*} \breve{C}^{w}>{ }^{*} \check{C}^{w}$ and subsequently $>K^{w}$ in Eyak. Labialized velar reflexes of ${ }^{*} C^{w}$ in Tlingit are as frequent as the same reflexes of ${ }^{*} \check{C}^{w}$ ( ${ }^{*} K^{w}$ in Leer's terms). There are several examples of PND ${ }^{*} \breve{C} /{ }^{*} \breve{C}^{w}$ duplicates ${ }^{26}$. Development of the PA series ${ }^{*} K-$ into Athabaskan front affricates / fricatives is an entirely different process, since it deals with nonlabialized palatal phonemes.

My presumably intermediate ("sibilant-hissing") series * ${ }^{*}$ - is represented with scant examples and has no evident labialized counterpart - except for a quite hypothetical ${ }^{*}{ }^{w}$, i.e. Leer's "extrasystematic fricative correspondences", which he interprets as "s $x$ and *šx (Leer 2008a: 170$)^{27}$.

My series ${ }^{*} \chi^{w}$, in which PEA sibilants correspond to Tlingit laterals, is interpreted as "labialized laterals" based on the principle of "what else?", especially since the non-labialized series $* \chi$ otherwise remains without its liabialized counterpart. Leer regards Tlingit laterals, corresponding to PEA sibilants, as a result of "lateralization" of the latter due to fusion with t-prefixes, but this does not explain the presence of the series ${ }^{*} \chi^{w}$ in root-medial position. Eyak-Athabaskan reflexes of the series ${ }^{*} \chi^{w}$ show that it has effectively merged with ${ }^{*} C^{w}{ }_{-}$, including subsequent delabialization.

As is evident from Leer's solutions, he avoids reconstructing any phonemes that would exceed the typological limits of the well-known Na-Dene systems. I, however, hold the opinion that one of the main difficulties in reconstruction may be overcome only if we refute the widespread conception that the ancestral language must look like its descendents on the phonemic level, even though their systems may actually form a typological unity with those attested in genetically unrelated, but contiguous languages. The complexity of sound correspondences between Tlingit and Proto-Eyak-Athabaskan aroused the suspicion that Tlingit was "a portmanteau language family" (Leer 1990), but this hypothesis seems untenable.

A characteristic feature of the Na-Dene family is absence of velar obstruents, and only external comparison with other members of the Dene-Caucasian macrofamily may elucidate their reflexes in PND. Some hope remains that external comparison will also help us solve the problem of interpreting Na-Dene correspondences between front affricates/fricatives.

\section{Some series of front and lateral affricates and fricatives}

As an example of my reconstruction, I have chosen three disputable series, namely, the series ${ }^{*} C^{w},{ }^{*} C$ and ${ }^{*} \chi^{w}$. Restrictions on volume have forced me to minimize adduced data, comments

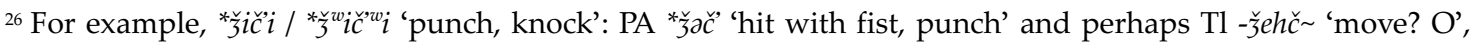
$Y$-žehč 'become surprised', NTl ya-ti-že:č (tr.) 'surprise, astonish, amaze' vs. E O-gulk' 'punch, knock, strike with closed fist'; * ${ }^{2} a s ̌ V /{ }^{*} \check{c}^{w} a{ }^{\check{w}}{ }^{w} V$ 'thick': E -čahš [adj.] 'thick (in least dimension), coarse' [with a secondary final fricative]

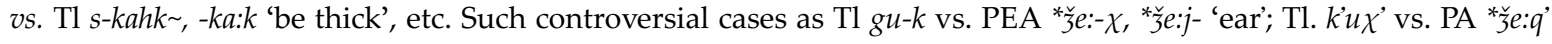
'pitch' and Tl ga;n 'menstrual discharge', E gama-G '(soft wet) mud' vs. PA *̌̌a:n 'muddy water, soft mud' continue this row of irregularities, centered around the fluctuation between ${ }^{*} \breve{C}^{w}$ and ${ }^{*} \check{C}$.

${ }^{27}$ Some remnants of the old series ${ }^{*} C^{w}$ are possibly reflected in PA alternations ${ }^{*} \mathrm{~K}^{\mathrm{w}} /{ }^{*} \mathrm{C}^{\mathrm{w}}$, corresponding to $\mathrm{Tl}$, E $K\left(^{w}\right)$, formally reconstructed as ${ }^{*} \mathrm{~K}\left({ }^{\mathrm{w}}\right)$ with irregular PA variants. For example: Tl $x^{\prime} u h k^{\prime} \sim$ 'become steamed,

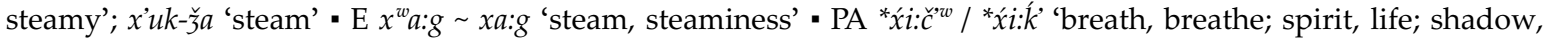
ghost' < PND * $x^{w} \ddot{a} c^{\prime} w i$ (??) 'steam, breath'; TL =Ya-2a;k 'place for, room for, time for' - E Op-2a:g [postposition] 'middle, center of O; Op's waist' - PA *ni:亏̌w/*ni:ǵ 'middle; waist; seed, pit' < PND *ńä̌́s $i$ (??) 'middle'.
} 
and references; a detailed account of my reconstruction, including the entire data corpus, thorough analysis of PND sound correspondences and an accurate review of previous versions of PND reconstruction will be published elsewhere.

Semantic reconstruction of PND roots, given below, is rather approximate. A question mark after a protoform does not denote my doubt as to the very fact of comparison, but only points to some irregularity of sound correspondences (as a rule, concerning the distribution of glottalized obstruents, affricate/fricative fluctuation and reconstruction of root-medial sonorants).

Syntactical abbreviations: $\mathrm{S}=$ subject, $\mathrm{O}=$ object.

${ }^{*} \mathrm{C}^{\mathrm{w}}$-series

\section{PND * $3{ }^{\mathrm{w}}>$ Tl. g( ${ }^{(\mathrm{w})}, \mathrm{E} 3, \mathrm{PA}^{*} 3$}

Root-initial: $1 .{ }^{*} 3^{\mathrm{w}}$ ans ${ }^{\prime \mathrm{w}} \mathrm{V}$ 'plead, pray' $\left(\# 1107^{28}\right)$ : Tl $\chi^{\prime} e-d-g a 2 x^{\prime} \sim$ 'pray'; $\chi$ 'a-ga; $x$ ' 'prayer'; $d$-ga?x' 'become annoyed by noise' - E $d$-do-za:c' 'S pleads, implores, begs, prays'; (O?-)d-t-za:c' 'S begs (O?)' - Leer 2008: 11; 2008a \#1429.

2. * $3^{\mathrm{w}}$ At'E 'shake, move upside down' (\#1134) - Tl k-gwart' '(container) moves upside down' - PA * zət' 'shake, rattle'.

3. ${ }^{*} 3^{\mathrm{w}} \ddot{\mathrm{n}} \mathrm{G}^{\mathrm{W} V}$ 'act with end of stick-like instrument' (\#1108): Tl -guhG 'push'; tu-guhG pl. 'run'; $k$-3-guhG $\sim$ '(hair, plants) push up (out of scalp, ground)' - E $d$-zahG -3ahG- $t$ 'cane, staff, walking-stick, prop, wand', etc. ${ }^{30}$ - Leer 2008: 11; 2008 a \#16.

4. ${ }^{*} 3^{\mathrm{w}} \mathrm{ELV}$ 'hump, hill' (\#1110): Tl guhL 'bump, hump' - PA * 3 əł 'mountain (above timberline)' - Leer 2008: 12.

5. *3wiwV 'good, pleasant' (\#319): Tl s-gu: 'be joyful, fun'; sa-gu 'joy, fun' - E -zu: 'good, nice, pretty, etc.'; łə-3U? 'S improves (his lot) somewhat' - Leer 2008: 11; 2008a \#15. Cf. Leer 1992 $\# 100$.

6. ${ }^{*} 3^{\mathrm{w}}$ is ${ }^{\mathrm{w}} \mathrm{V}$ 'cup, receptacle, calyx' (\#1113): Tl gux'-a 'cup'; -gu2x’ 'dip (water) out' - E $-d-t-3 i c$ '- $t$ 'receptacle and/or calyx, sepals, "stem" (of berry)'; $O-l \chi$ - $t$-zic' 'S removes calyx (etc.) from $\mathrm{O}$ (berry)'.

Root-medial: 1. *2əz ${ }^{\mathrm{w} \partial}$ 'move the foot, step' (\#32): Tl Y-ž-2a?g 'stagger (of wounded animal or person)' [with *nə-(c-)də- 'mis-'] - E O-2e?z 'S touches, affects, acts upon O with foot'; O-t-2e2z 'S moves, fixes position, substantially affects $\mathrm{O}$ with foot' - PA * $3 e: 3 z$ 'move the foot, step', *ń(c-)d-2e:3z 'misstep' - Leer 2008: 18-19; 2008a \#46a, b.

2. ${ }^{*} \mathrm{dEm} 3^{\mathrm{w} i} \sim-\mathrm{w}^{\mathrm{w}}$ - 'skin, fur' (\#209): Tl =duhg 'skin' $\cdot \mathrm{PA} * \mathrm{du}:(1) 3$ 'fur'.

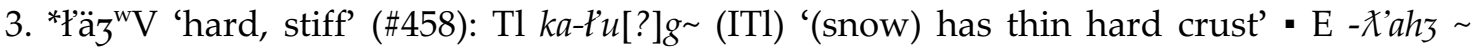
- $X^{\prime}$ 'ar3 ' $\mathrm{S}$ is tightly packed, firm, rigid, stiff, hard, intractable, immobile'.

4. *t'ä ${ }^{\mathrm{w} V}$ 'stiff, numb' (\#824): Tl -t'izg 'become stiff' - E -t'aßz 'S (place) becomes impassable'; do-t'arz 'S (place) becomes impassable'.

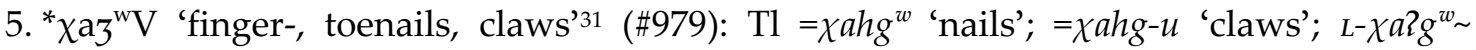
'hang on with nails' - E -y-t-xahz-ł 'nails, claws'; -qi:y-t-xahz-t- 'toenails, claws' - Leer 2008: 18; 2008 a \#45.

\footnotetext{
${ }^{28}$ The number refers to the record number of the etymology in the database.

${ }^{29}$ References are given without any mark if Leer's and my own comparison of Tlingit with Eyak and/or Athabaskan data coincides; they are preceded by "Cf." in case of difference.

${ }^{30} \mathrm{Cf}$. also $2 a d-$ ta-zih ' $\mathrm{S}$ moves self along in boat by poling' with a different vowel.
} 


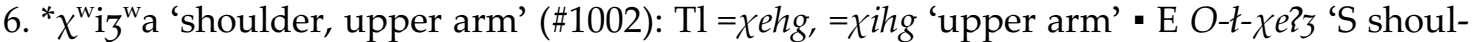
ders $\mathrm{O}, \mathrm{S}$ picks $\mathrm{O}$ up onto shoulders, $\mathrm{S}$ carries $\mathrm{O}$ on shoulders, on head' $-\mathrm{PA}{ }^{*} \chi^{\mathrm{w}} \mathrm{a} 3,{ }^{*} \chi^{\mathrm{w}} \mathrm{\partial}$ 'shoulder; carry on shoulders' - Leer 2008: 18; 2008a \#44.

PND * $\mathrm{c}^{\mathrm{w}}->\mathrm{Tl} \mathrm{k}\left({ }^{\mathrm{w}}\right)-/ \mathrm{g}\left({ }^{\mathrm{w}}\right)-, \mathrm{E} \mathrm{c}-, \mathrm{PA} * \mathrm{c}-$

Only root-initial: $1 .{ }^{*} \mathrm{C}^{\mathrm{w} a}$ 'change, distribute' (\#76): Tl $k$-t-ga: 'distribute, hand out, pass out (esp. definite amount given out at party)' - E O-t-ca? 'S gives $\mathrm{O}$ (possession of deceased) away at potlatch'; $\mathrm{O}-2-c a$ 'S buys $\mathrm{O}$ (with cash, not on credit)'.

2. * $\mathrm{c}^{\mathrm{w}}$ äja 'see, look' (\#77): Tl s-kuh 'come to know' - E O-2-l-łz-ca 'S stares (penetratingly) at $\mathrm{O}$, looks hard at $\mathrm{O}$ '; $\mathrm{O}-\nmid$ - $c a$ ' $\mathrm{O}$ is, becomes (clearly) visible, $\mathrm{O}$ shows', etc. - PA *ca:ń 'see, look' - Leer 2008: 12; 2008a \#21.

3. * ${ }^{*} \mathrm{w} E \mathrm{E}$ 'paired with, whole' (\#79): $\mathrm{Tl}=k i g$, (ITl) kihg 'paired with'; =kig-i 'one of a pair, half (of symmetrical obj.)' - PA *coǵ 'whole, entire, all'.

4. * ${ }^{\mathrm{w}}$ ELE 'hole' (\#80): Tl =kuht 'navel', (NTl) hà:t kù:t 'whirlpool' - PA *cəu(ə) 'small opening, gap; anus, rectum'; *ta:-cəLə 'open hole in ice'.

5. * ${ }^{\mathrm{w}} \mathrm{Es}$ 'V 'extinguish' (\#84): Tl k-kis’ 'become extinguished' - PA *cos (perf. *cas) 'extinguish (intr.)' - Leer 2008a \#25.

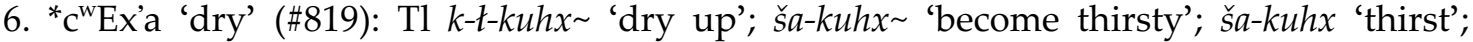
k-s-kuhx 'bail'32 - PA *ca:ḱk' [and *za:ḱk' < *d-ca:ḱ'] 'dry (by evaporation), become dessicated' Leer 2008: $8 ; 12-13$; 2008a \#3b.

7. * $\mathrm{c}^{\mathrm{w}}$ ina 'breechclout' (\#89): $\mathrm{Tl}=k u: n$ 'hem' - E $d$-cil-G 'S is naked'; O-t-cį-G 'S undresses $\mathrm{O}$, strips O naked' [-G 'negative/privative'] - PA *ca:n 'breechclout' - Leer 2008: 12; 2008a \#20.

8. ${ }^{*} \mathrm{C}^{\mathrm{W}}$ inł’ 'ashes' (\#90): Tl ket'-t' 'cedar bark ashes'; ke;t' 'dandruff'; ši-ke[?]' (tr.) 'burn to

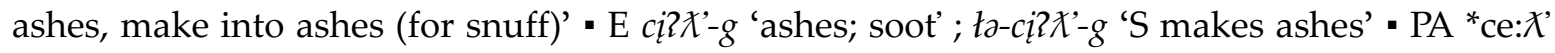
'ashes, embers' - Leer 1992 \#20; 2008: 12; 2008a \#19.

9. ${ }^{*} \mathrm{C}^{\mathrm{w}}$ ińE 'flee, run to safety' (\#91): Tl -ke2-ł’ pl. 'run away'; caus. O-ł-keł’ 'chase pl. O away' - E cįz(-l-) 'disorder, confusion' - PA *cəń- (pref.) 'flee, run to safety, for one’s life, in fear/panic'.

10. * $\mathrm{C}^{\mathrm{w}} \mathrm{imdV} \sim$-wd- 'snore, sleep' (\#88): Tl 2a-kihd 'snore' - E curd [n.] 'sleep'; cu2d- $t$ [n.] 'sleep'; -cu2d -cuhd 'S sleeps, goes to sleep' - Leer 1992 \#174; 2008: 13; 2008a \#23.

11. ${ }^{*} \mathrm{C}^{\mathrm{w}} \mathrm{iz} \mathrm{V}$ 'thin, loose (snow)' (\#87): Tl $k-k e[?] z^{\sim}$ '(dry snow) becomes loosely piled up'; $=k a-k e z-g^{w}$ 'light dry snow'33 - E -ciz-g [adj.] 'narrow, thin', -ci3-g 'S is thin', etc. - Leer 2008: 13; $2008 \mathrm{a} \# 24$.

PND * $c^{\prime w}>$ Tl k'( $\left.{ }^{w}\right)-, k^{\prime}\left({ }^{w}\right) / g\left({ }^{w}\right)$, E c', PA *c'

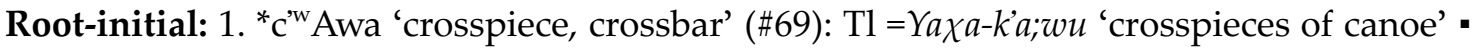
PA *ca:? 'crosspiece, crossbar' - Leer 2008: 16; 2008a \#36.

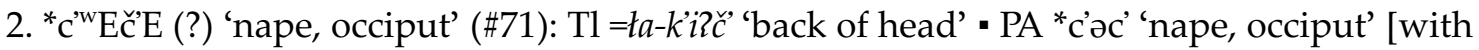
c' instead of ${ }^{*}$ c' by assimilation] - Cf. Leer 2008: 17; 2008a \#42.

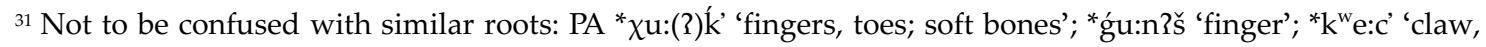

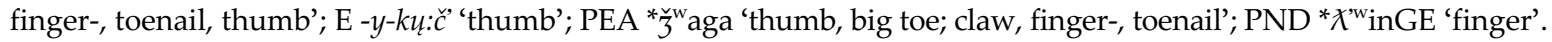

32 And - $x u h k$ 'to dry'; =xuhk 'dry' with a metathesis, perhaps under the influence of $q u-k-x a[?] k$ 'weather becomes dry and crisp', quh-xahk 'dry weather', cognate with PA *x́a:k' 'hard and dry' < PND *xAk'a 'dry' (\#919).

${ }^{33}$ Cf. also Tl $k e x^{w}-k$, (ITl, EN) -kex ${ }^{w}-t$ 'be light, insubstantial'; =ka-kex ${ }^{w}-k$ 'light dry (snow)'; $k-3-k e x^{w}-\mathrm{k}$ 'be po-

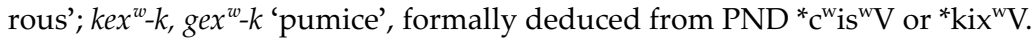




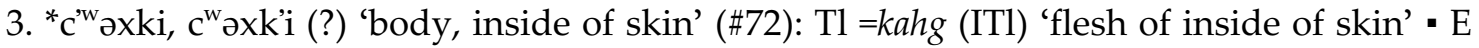
-c'eh $\chi k$ ' [a misrecord of $-x k$ '?] 'inside of pelt' - PA *ci:[x́X] 'body, outer skin' [with a cluster impeding precise reconstruction] - Cf. Leer $1992 \# 173$.

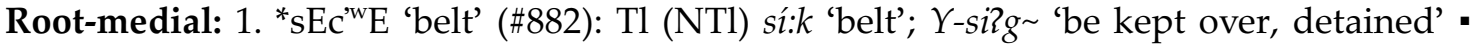
PA * səc' 'belt' 34 .

2. * ${ }^{\mathrm{w}}{ }^{\mathrm{w}} \mathrm{c}^{\mathrm{w} \mathrm{V}} \mathrm{V}$ (?) 'squeeze, mash (berries)' (\#479): Tl $k-t-x a h g^{w} \sim$ 'grind, whip up (soapberries)'; $k a-x a g^{w}-a$ 'pestle'; $x a g^{w}-\nmid i$ 'soapberries' - E O- $t-c$ ' $2 c$ ' 'S smashes, mashes, squeezes, expresses O; S makes O (berrymash)'; c'e?c' 'berrymash' - Leer 1992 \#181.

3. *t'Ec'wə 'thorny/stinging plant' (\#825): Tl t'u:k' 'nettles' - PA *t'e:c' 'conifer'.

\section{PND ${ }^{*} \mathbf{s}^{\mathrm{w}}>\mathrm{Tl} x\left({ }^{\mathrm{w}}\right), \mathrm{E} \mathrm{s}, \mathrm{PA}{ }^{*} \mathrm{~s}$}

Root-initial: $1 .{ }^{*} \mathrm{~s}^{\mathrm{w}} \mathrm{ak}$ 'wa (?) 'shell' (\#672): Tl =ša-ka-xahg-u 'skull'; =xahg-i, xa:k 'skeleton'; $x a: g$ 'empty shell', etc. - E sahx $x^{w} \sim$ sahx 'cockle, pecten' [with irregular fricative] - PA *-sa:3ḱ 'shell, pot' - Tl (Yak) sa: $x^{w}$ 'cockles' is an Eyak loan - Leer 2008: 8; 2008 a \#2.

2. * ${ }^{\mathrm{w}} \mathrm{Ag}^{\mathrm{w}} \mathrm{a}$ 'sand, gravel' (\#918): Tl $x a g^{w}$ 'sandbar' - PA *sa:x́ (< ${ }^{*} \mathrm{sa}: g$ ) 'sand, gravel' - Leer 2008: 8; Leer 2008a \#3.

3. * $\mathrm{S}^{\mathrm{w}} \mathrm{EdE}$ 'fall (animate subj.)' (\#1109): $\mathrm{Tl}$ 3-gihd 'anim. moves rapidly, falls'; Adv=3-gihd 'act thus'; $k-u-3-g i d-a G^{w}, k-u-s-g i d-a G^{w}$ 'show off' $\left[<{ }^{*} 3^{w} E d E<{ }^{*} \mathrm{~d}(\partial)-s^{w} E d E\right] \cdot P A{ }^{*}$ səd 'fall; spend period of time; undergo an experience' - Cf. Leer 2008: 10; Leer 2008a \#13a, b.

4. ${ }^{*} \mathrm{~S}^{\mathrm{w}} \partial \mathrm{c}^{\mathrm{w} \mathrm{V}} \mathrm{V}$ 'squeeze, mash (berries)' (\#479) - see under the root-medial ${ }^{*} \mathrm{C}^{\mathrm{w} w}$.

5. * ${ }^{\mathrm{w}}$ ədE 'extend, pull' (\#686): Tl -xart 'pull, tighten'; sg. 'become fastened, extend, hand'; $k$-xait sg. 'resemble'; xahd-a 'veil' - E -sid pl. 'S (of definite length) extend'; $x d$-sid pl. 'S (of definite length) extend'; $t$-sid pl. 'S extend comparatively', etc. - PA *səd 'be far, distant, deep, long in duration' - Leer 2008: 9. Cf. Leer 1992 \#70; 2008a \#7.

6. * ${ }^{w}$ Ena -ń-, -m- 'frown (with displeasure), punish' (\#684): Tl 2a-s-xizn 'frown (with bad-temper, displeasure)' - PA *sa:N2 'beat one's wife'.

7. * ${ }^{\mathrm{w}} \mathrm{EnE} \sim$-ń- 'mark, recognize' (\#678): Tl (Y-)xuhn pl. 'move faces'; (NTl) ya-di-xu:n 'show faces (as entering in ceremonial dance); peer, peep' - PA *son? -ń 'mark, recognize'.

8. * ${ }^{\text {w}}{ }^{2}$ əs'E 'skin' (\#687): $\mathrm{Tl}=x a 2 s$ '(-i) 'fish skin'; -xa2s' 'scrape, slime (fish)' - E -sic' [ti:l-class] 'skin (of fish)' - PA *səc' 'skin, hide, pelt; skin bag' - Leer 2008: 8.

9. * ${ }^{w}$ Et’i (?) 'sweep, scrape, rake' (\#682): Tl -xi:t’ 'sweep'; t-xi:t’ 'scrape cambium'; xit'-a 'broom, bark sharper' - E O-še:t' 'S scrapes O (inner side of bark) for cambium' [with irregular š- perhaps under the influence of $O-t$-šu:t' ' $S$ pries $O$ loose, moves $O$ in arc with pole'] - PA *si:3t' 'rake sand, dirt; pour grain-like objects' - Leer 1992 \#123; 2008: 9; 2008a \#6, 11.

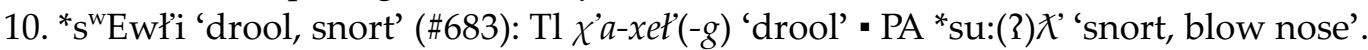

11. ' ${ }^{*} \mathrm{w} E x ' E$ 'fall, move rapidly' (\#685): Tl s-xihx 'compact obj. moves through space, moves rapidly, falls'; Y-s-xihx 'occur'; šu-s-xihx 'become depleted'; 'fall, move through space (sg.)' - Leer 2008: 8; 2008a \#4.

12. * ${ }^{w} \mathrm{w} i$ 'dusk, evening' (\#688): Tl $x e h=, x i h=$ 'dusk'; =xeh $Y-i$ '(mountain) shadow'; cf. $x a ́ z-n a h$ 'evening' - E se:- $t$ 'evening, twilight, dusk', $t$-se2-t ' $\mathrm{S}$ (impersonal) becomes evening, twilight falls' - Leer 2008: 9-10; 2008a \#9a, b.

13. *swidE 'draw, make furrow' (\#689): Tl -xihd 'make furrrow, plow'; xi:d 'furrow'; $k$-xihd 'push, poke with stick'; ž-xihd 'paint design, write'; kù-xid-a, -xizd-a 'brush, pen', etc. • PA *səd 'dig, draw, make furrow'35.

34 This root is homonymous with PA * səc' 'skin, hide, pelt; skin bag', for notes on it see below under ${ }^{*}{ }^{w}$-.

${ }^{35} \mathrm{It}$ is unclear whether $\mathrm{E} \mathrm{O}$-sehd ' $\mathrm{S}$ trips, stumbles over $\mathrm{O}$ ' belongs here. 
14. * ${ }^{w} \mathrm{w} i \mathrm{dV}$ 'ribs together with spine, comb' (\#690): Tl xe:d-u 'comb' • E -dl-si::d -sị:t' 'ribs, ribs together with spine'

Root-medial: 1 . ${ }^{*}{ }^{\mathrm{w}} \mathrm{Es}^{\mathrm{w}} \mathrm{a}$ 'edible root' (\#155): Tl ku:x 'Kamchatka lily root [Fritillaria camtschatcensis]' - PA *čw a:s 'Hedysarum alpinum, Indian potato'36 - Leer 2008a \#76.

2. * ${ }^{*}{ }^{\mathrm{w}} \mathrm{Es}^{\mathrm{w}} \mathrm{E}$ 'stone' (\#476): Tl ł'ehx (ITl) “"“aluminium”, a gray rock' - PA *c’os 'rock, stone'.

3. *näs ${ }^{\mathrm{w} E}$, *nä(n) $3^{\mathrm{w} E}$ (?) 'downriver, out to sea' (\#579): Tl 2i2x- (2ix-) [dir.] 'downriver, south' - PA *ńəsə 'ahead, forward, out on open water, over fire' - Irregular reflex in Eyak: lahz [preverb] 'forward; forward out to sea, out at sea, south'; Op-lahz -lahz -nahs- [postposition] 'forward, in front of, on one side of, out to sea from, south of'; $\chi$-lahs-d 'in front, out at sea, south, "ouside" (over the Gulf of Alaska)' < *näs ${ }^{w} \mathrm{E} /{ }^{*}$ nä ${ }^{\mathrm{w}} \mathrm{E}$ (?) and 2i:z-iz- [postpositional phrase] 'in bow of boat', \{ị:3-iz- $\chi$ 'forward, in front, out to sea, overseas, south, to Seattle' < *nänz ${ }^{w} E(\text { ?) })^{37}$ - Leer 2008:17; 2008a \#43a.

PND * ${ }^{\prime w}>$ Tl $x^{\prime}\left({ }^{w}\right)$, E c', PA *c'-, c's

Root-initial: 1. ${ }^{*} \mathrm{~s}^{\mathrm{w}} \mathrm{E}[\mathrm{j}] \mathrm{i}$ (?) 'straight, true' (\#667): Tl $x^{\prime} e:-\mathrm{G} a$ 'true' - PA ${ }^{*} \mathrm{c} \mathrm{i}:=$ 'straight, directly' - Leer 2008: 16; 2008a \#39.

2. *'swindE 'fall, sink, etc.' (\#898): Tl ša-s-x’hd 'become uprooted'; x’i:dadi, x'i:tadi 'uprooted stump' - PA *cod 'fall, sink; event occurs, time passes' - Leer 2008: 16, 37-38; Leer 1992 \#79.

Root-medial: 1. *2is' ${ }^{\text {'w }} \sim$ ń- (?) 'call, summon' (\#38): Tl -2i2x’ 'call; invite'; qu-2i:x' 'party' • $\mathrm{E} O-2-2 e h z$ 'S calls, summons, invites (for any reason, or to potlatch, party)' [with irregular loss of glottalization].

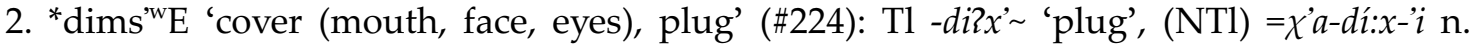

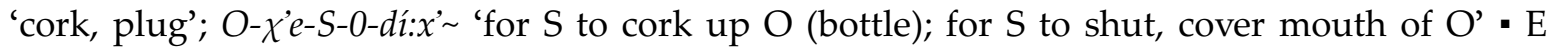

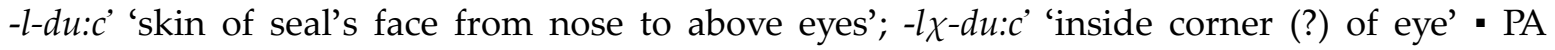
*du:n?c', *di:n?c' 'eyelid, eyelash, eyebrow'.

3. *X'is'wa 'trash, dirt' (\#514): Tl -X'ihx 'become dirty (bestrewn with trash)'; Xihx 'trash';

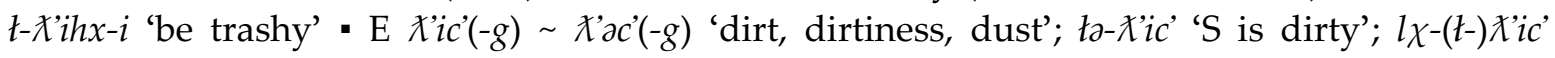
$\left(\sim-X^{\prime} \partial c^{\prime}\right)$ 'slush, wet snow' PA *X’a:(2)c' -3-38 - Leer 2008: 21; 2008a \#53a.

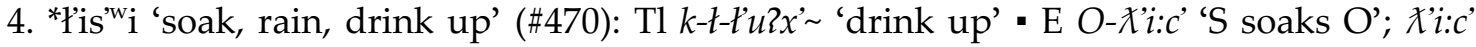
'sth. is thoroughly soaked' - PA * Xi:(2)c' 'rain clouds, shower moves'.

5. " $\mathrm{q}^{\mathrm{w}} \mathrm{Es}^{\mathrm{w}} \mathrm{\partial}$ ' 'enclosed/sticklike object moves' (\#643): Tl s-qu2x’ 'sticklike obj. falls over'; qu:x' 'fort'; (MS) O-qu2x' '(anim.) rolls (on the ground)' - PA * $\mathrm{q}^{\mathrm{w}} \mathrm{e}$ :[2]c', *quc' 'enclosed object moves independently' - Leer 2008:4, 20; Leer 2008a \#50.

6. 't'As'wa 'cut' (\#817): Tl -t'arx' 'cut in small pieces; flick with fingers or thumb'; kù-t'a; $x^{\prime}-a$, -t'ax'-a 'marble; inch' - PA *t'a:c' 'cut (out, into shape)'.

7. “'”is ${ }^{\text {'wV } V ~ ' i c e ; ~ f r e e z e ' ~(\# 837): ~ T l ~ L-t ' i: x ' ~ ' b e c o m e ~ f r o z e n ', ~(N T l) ~ t ' i ́: x ' ~ ' i c e ' ~-~ E ~ t ’ i c ' ~[d-c l a s s] ~}$ 'ice'; l $\chi$-t'ic' 'hail'; $g_{L}-t$ 'ic' 'icicle'; dz-t'ic' 'S freezes', etc. - Leer 2008: 19-20; 2008a \#49a, b, c.

8. * $\chi$ 'Es' ${ }^{\prime} \mathrm{i}$ 'round, round object' (\#1030): Tl $\chi$ 'ix' 'eel eggs' - PA * $\chi \mathrm{i}: \mathrm{c}^{\prime},{ }^{*} \chi \mathrm{e}: \mathrm{s},{ }^{*} \chi \partial \mathrm{s}$ 'cylindrical; square; turn, roll'.

${ }^{36}$ E ča:s 'Hedysarum alpinum plant; edible Hedysarum root, Indian potatoes'; Tl ca:c 'plant with edible root (Hedysarum?)' are borrowed from Athabaskan (Leer 2008a \#76).

${ }^{37} \mathrm{Cf}$. the similar appearance of an affricate in Eyak in PND *niwsi, *niwzi 'long fiber, meat slab' > Tl Yihs 'horse clam [Tresus capax]' and PA *nu:(2)s 'long fiber of meat, fish gut with stringy end, long tail', as opposed to E

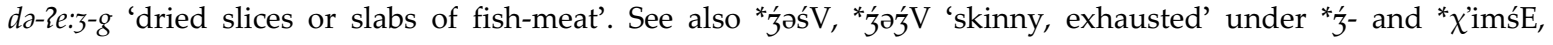
* $\chi$ 'imźzE 'sour, stinking' under*-ź-.

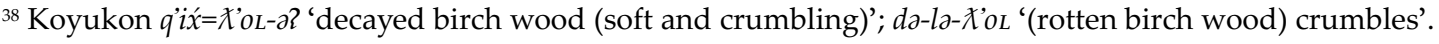


9. ${ }^{*} 3^{\mathrm{w}}$ ans ${ }^{\text {'w } V}$ 'plead, pray' - see above (under ${ }^{*} 3^{\mathrm{w}}$ ).

10. ${ }^{*} 3^{\mathrm{w}}$ is $^{\mathrm{sw}} \mathrm{V}$ 'cup, receptacle, calyx' - see above (under ${ }^{*} 3^{\mathrm{w}}$ ).

\section{*Ć-series}

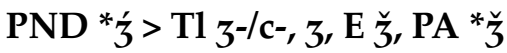

Root-initial: 1. *3́AmAł’E 'wart' (\#1097): Tl Ya-zat' (Yak) 'lumpy face' - PA *̌̌əməł 'wart'.

2. *'́EnE 'muskrat' [Ondatra zibethicus] (\#1098): Tl cin 'muskrat' - PA *̌̌̆on 'muskrat'.

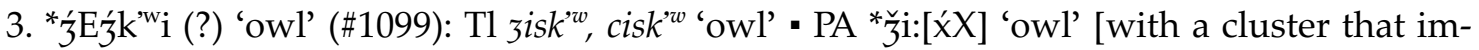
pedes precise reconstruction].

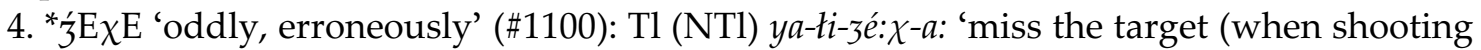
in basketball)' - PA *̌̌ $\left({ }^{\mathrm{w}}\right) \partial \chi$ 'oddly, strangely, badly'.

5. *źośV 'thong, lace' (\#1102): Tl k-za[?]s 'lace'; zàs, za;s 'thonging, lacing' - E O-žiš 'S makes $\mathrm{O}$ (platform, or rack for drying fish?)'.

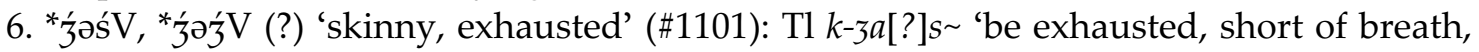
tired out'; $k a-t i-z a: s$ (tr.) 'exhaust, tire out' - E -žžz̆ $g$ 'S is very narrow, thin, skinny' [irregular affricate, see footnote to ${ }^{*} \check{\mathrm{C}}^{\mathrm{w}} \mathrm{Es}{ }^{\mathrm{w}} \mathrm{a}$ above].

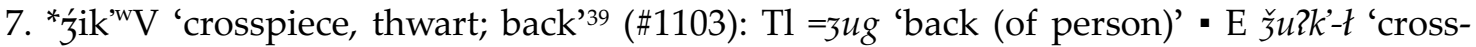
piece (of canoe), thwart'; O-t-̌̌̆ulk' 'S makes or installs O (thwart, crosspiece)'.

8. *'́indE 'round, oval, round object' (\#1104): Tl ce?d [also cert'], (NTl) cé:t 'plant with edible root' - PA *̌̌i:nd 'spherical, round, oval; ball-like gut, pyloric caecum'

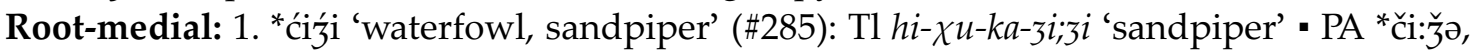
* ̌̌i: ̌̌ว 'waterfowl'40.

2. *hEక́a 'singe' (\#337): Tl -hìz 'singe fur' • PA *ha:3̌̌ 'singe'.

3. *wAźEnxE 'elk, caribou' (\#840): T1 wazix, wacix 'caribou'41 - PA *wəžən?x́ ' caribou, elk, deer' 42 .

4. *yaźa, *yaśa (?) 'small’ (\#1079): Tl =Yaz-k’u, pl. -x’i ‘'small’ • E yahš 'doll'; -yahš '(woman's) child, (woman's) sister's child'; də-yahš 'S gives birth' - PA *ya:šw (ə) ' young, small, little; (woman's) child'. - The Tl affricate contrary to the PEA spirant is irregular.

\section{PND *ć- > Tl c-/3-, E č-, PA *̌̌-}

Only root-initial: 1 . *ćA 'beaver, hair seal' (\#61): Tl cah 'hair seal' - PA *ča:? 'beaver, seal'.

2. *ćEk'E 'stick, pole' (\#62): Tl -cihk 'roast on stick'; ci:k 'roasting stick' - PA *čə́k' -y? 'mainbeam, rail (of sled)'.

3. *ćEmE 'strong, hard' (\#63): Tl t-cihn 'make strong'; t-cihn (neg. -čihn) 'be strong', etc. PA *čəm? 'hard, packed'.

4. *ćE $\chi^{\text {'w } E ~ ' s t a k e, ~ d a m ~ u p ' ~(\# 64): ~ T l ~-c u 2 \chi \sim, ~-c i 2 ~} \chi^{w} \sim$ 'dam up' - PA *čəq' 'stake O; put/hang O on pole (/line)'.

${ }^{39}$ Cf. Ukrainian nопере́к 'waist', dial. nопе́рек 'lower part of back, back' as a development of the earlier meaning that still remains in попере́чка 'crosspiece, thwart', Russian nоперёк 'across, crosswise', etc.

${ }^{40} \mathrm{E}$ zi:zi: 'sandpiper' is borrowed from Tlingit.

${ }^{41}$ Here $^{*}$-ź- is treated as a root-initial consonant.

${ }^{42}$ Tsimshian (only Gitksan?) wizix 'caribou', North Wakashan Heiltsuk (Klemtu) w'əzík, Haisla w'əzik 'moose' (without any South Wakashan cognates) are borrowings from Tlingit. 
5. *ćəGV 'push (with) sticklike object end forward' (\#65): Tl cahG 'push (with) sticklike obj. end forward'; caG-a 'pushing instrument: pole, rod, antlers', etc. - E -čaG 'S uses a fork'; O-ł-čaG 'S lifts, handles $\mathrm{O}$ with a fork'; čaGt 'fork, forked stick, table-fork'.

6. *ćinE (?) 'bad, evil, difficult' (\#1105): Tl -3i: 'be difficult' - Eyak: -šì-ah [adj.] 'bad, evil, anger, offense, ugly, mean, unclean, spoiled, naughty, nasty, queer, sickly, disguisting' [with an irregular fricative $\check{s}$ - instead of $\check{c}$-] • PA *čəńz 'bad; stingy'.

7. *ćiźi ' waterfowl, sandpiper' - see under root-medial *-ź-.

\section{PND *ć' > Tl c', E č', PA * č́}

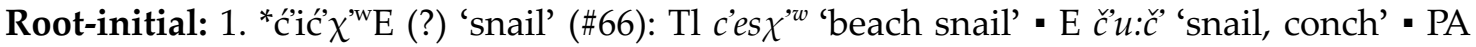
*Č̀ $[\hat{X} X]$ 'snail' [with a cluster that impedes precise reconstruction].

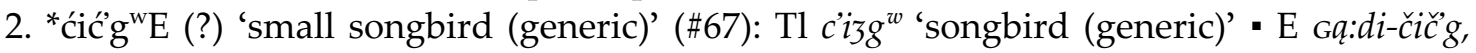
Ga: $d i$-čǐ̆g '(any) small non-aquatic songbird' - PA *čəčğg 'small songbird (“American sparrows")'.

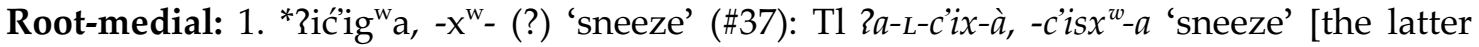
form with reduplication] - E ła-Zašg 'S sneezes'; Zašg 'sneeze' - PA *2ačğ 'sneeze'.

2. *ćić'gw $E$ (?) 'small songbird (generic)' -- see above (under *ć-).

3. *ćić' $\chi^{\text {'w } E ~(?) ~ ' s n a i l ' ~--~ s e e ~ a b o v e ~(u n d e r ~ * c ́-) . ~}$

4. ${ }^{*} \mathrm{~g}^{\mathrm{w}} \mathrm{imV} \mathrm{c}^{\prime} \mathrm{V},{ }^{*} \mathrm{k}^{\text {'w }}$ - (?) 'a plant with edible roots' (\#314): Tl kunc' 'swamp plant (death camass?), potato' - E guč 'Indian potato' [Apios americana?] ${ }^{43}$.

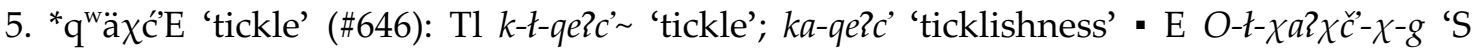

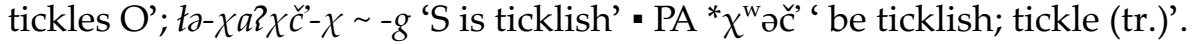

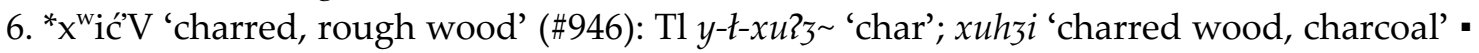

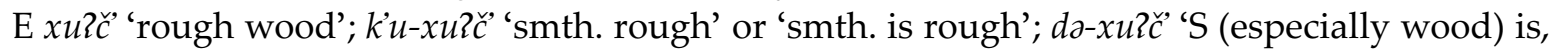
becomes rough from abrasion'. - Cf. Leer $1992 \# 41$.

7. * $\chi$ EmVć’ə (?) 'egg, testicle' (\#1058): Tl (NTl) -k'unc'- $i$ 'testicles (of moose, caribou)' [with irregular $k^{w}$ - instead of ${ }^{*} \chi^{w}$ - due to contamination with $k^{\prime} u n c$ ' 'swamp plant', see above

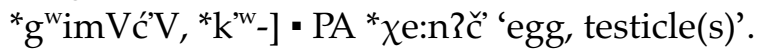

\section{PND *ś > Tl s, E ̌s, PA * $\check{s}^{w}$}

Root-initial: 1. *śAwni 'good, normal' (\#658): Tl sa:n-i 'medium amount' - PA *̌sw u:n 'good, well, nice'.

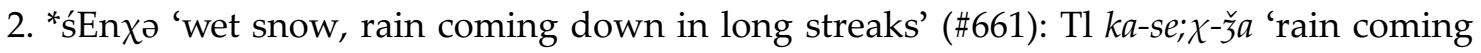
down in long streaks' - PA * ${ }^{w} \mathrm{e}$ : $\chi$ 'wet, slushy snow'.

3. *'ś[j]i, *wəśə[j]i (?) 'name' (\#662): Tl -sa: 'to name'; sà 'name'; -sąY 'name off' - E wašeh, -wašeh 'name' - PA *2u:-šwi: 'name; call/mention by name' - Leer 1992 \#126; 2008: 5.

4. *śEji ‘voice' (\#659): Tl =se 'voice’ - PA *̌̌wi: 'voice' - Cf. Leer 1992 \#127.

5. *śi[lw]V (?) 'flowing water' (\#664): Tl si:w 'rain' - E ši: šį: 'creek, stream’.

6. “śiwV 'sleep' (\#663): Tl t-si2s, -su2s 'lull to sleep' [with reduplication] - E 2a-šu:-kih 'asleep' (of baby) [-kih diminutive suffix] - Leer $1992 \# 166$.

43 This PND root as well as the separate PA root ${ }^{*}$ Gu:n?c' 'wild celery (Heracleum lanatum), wild rhubarb (Polygonum alaskanum)' are ancient, but probably independent borrowings from the Penutian languages, cf.

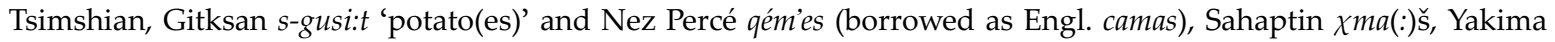

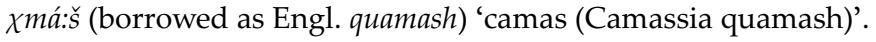


Root-medial: 1. *däśV 'foam, (foamy) juice' (\#183): Tl de;s-a 'clam juice used for seasoning' - E da:š 'foam, froth, white foam as found on beach, on beer'; də-da:š 'S foams'.

2. *gwiśi 'vagina' (\#317): $\mathrm{Tl}=g u$;s 'vagina' - PA *ǵu:š 'vagina'.

3. *šEmśi -wś- 'beak, crooked stick' (\#702): Tl ši[?]s (Swanton) 'stick game’ [also ši[?]šd (Swanton) 'lucky gambling stick' with irregular -š-] - PA *šu:(2)̌̌ 'beak; snow playing-stick'.

4. * wəśV 'dry, roast' (\#862): Tl t-wahs 'become scorched, roasted by fire' - E we:š(-g) 'rack of sticks for drying fish (outdoors)'.

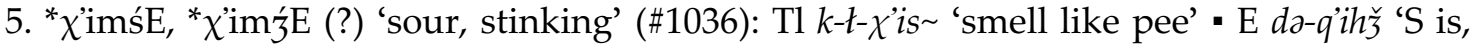
becomes rancid, bitter, sour, spoiled' 44 PA *q'u:nš $\sim-\check{z}$ - 'sour, rancid'.

6. *'วəś $\mathrm{V}$ 'thong, lace, tie' - see under root-initial *'́ .

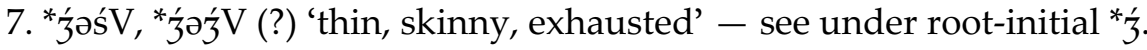

PND *św (?) > Tl s-/̌̌-, E x-, PA *'́x-

Only root-initial: $1 .{ }^{*} \mathrm{~s}^{\mathrm{w}} \mathrm{a}$ 'south, summer' (\#179): Tl sah-n Yah 'Southern (Craig-Klawock) Tlingits'; sa:-nax 'south wind' - Eyak ł-xa? 'it becomes summer' - Leer 1992 \#165.

2. *'sw[a]na 'old (person, animal)' (\#920): Tl $d$-šahn 'become old, gray'; šahn 'old age, old person’ - PA *x́a:n ‘old (person, animal); old age’45 - Cf. Leer 1992 \#128; 2008: 5.

3. *'swonE 'cure shamanistically, medicine-man' (\#883): Tl -sa2n 'cure shamanistically' - E xi:l 'shaman, medicine-man, indian-doctor' - PA *x́ən 'spiritual power or medicine, medicine song' • Leer $1992 \# 168$; 2008 : 4.

\section{$* \chi^{w}$-series}

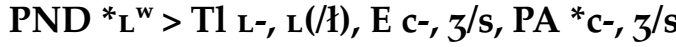

Root-initial: 1. ${ }^{*} \mathrm{~L}^{\mathrm{W}} \mathrm{EL}^{\mathrm{W}} \mathrm{\partial}$ 'hang' (\#521): Tl -Le?L 'hang slackly' - PA * ${ }^{*}$ ' 'hang (on string, rope)'. 2. ${ }^{*} \mathrm{~L}^{\mathrm{w}} \mathrm{Ex}{ }^{\mathrm{w}} \mathrm{E}$ 'peel' (\#533): Tl $-L i h x^{w} \sim$ 'skin peels off'; $t_{-L} L h x^{w} \sim$ 'skin peels off; eat by removing from skin or shell with thumb' - PA *cəx́- 'peeling bark, skin'.

Root-medial: 1. ${ }^{*} \mathrm{~g}^{\mathrm{w}} \mathrm{iL}^{\mathrm{w}} \mathrm{i}$ 'frail, small' (\#312): Tl $k$-d-geL 'be frail' - E -gehz - gihz $(-g) \sim-g e h s$ 'S is very poor, miserable, wretched, pitiable'; $d$-łz-gihz-g ' $\mathrm{S}$ (board) is useless'; $l \chi$ - $t$-guhz 'S (ber-

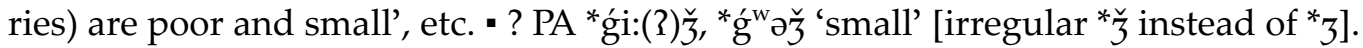

2. ${ }^{*}{ }^{\mathrm{w}} \mathrm{EL}_{\mathrm{L}}{ }^{\mathrm{w}} \mathrm{\partial}$ 'hang' - see under root-initial ${ }^{*} \mathrm{~L}^{\mathrm{w}}$.

3. *ńaL ${ }^{\mathrm{w} E}$ 'old (man, animal)' (\#576): Tl =2a:ti 'grandparent' • PA *ńrz 'old (man, animal)'.

4. * $\mathrm{x}^{\mathrm{w}} \mathrm{äL}^{\mathrm{w} a}$ 'fear, danger; monster' (\#928): Tl (NTl) xè:L 'thunderbird'; xè:L tá:x’a:yi: 'horsefly' - E $x^{w} a: s \sim x a: s$ 'lucky, ominous, tabu, dangerous, strange'; O-2-t-xa:s 'S abstains from, avoids tabu O'; laxis $x^{w} a: s$ [gerundive] 'fear, danger' - PA *x́a:3z y- 'fear, startle'.

PND * $\chi^{\mathrm{w}}->$ Tl $\chi-$, E c-, PA *c-

Only root-initial: $1 .{ }^{*} \chi^{\mathrm{w}} \mathrm{a}$ 'stout, thick' (\#494): Tl -ðah 'be stout' $\cdot \mathrm{PA}{ }^{*} \mathrm{ca}: 3-\mathrm{s}$ 'stout, thick in diameter' - Leer 2008: 29-30.

${ }^{44}$ See footnote to *näs ${ }^{w} \mathrm{E}$.

${ }^{45} \mathrm{E}$ xa:nih 'very old salmon, ready to die, red and turning yellow in spots' is borrowed from $\mathrm{Tl} x e h n$ 'spawned-out salmon with white scabs, ready to die', a derivative of -xe2n 'scabby; scratch oneself (esp. of dog)'. At the same time, E - a:- instead of -e:- points to an extinct root *xa:n 'old', contaminated with the phonetically similar Tlingit word. 
2. “ $\chi^{\mathrm{w}} \mathrm{ag}^{\mathrm{w}} \mathrm{a}$ 'old, long ago' (\#497): Tl オagw 'always (in past)'; オag- $u=$ 'old' - E cahg(-t) 'legend, myth'; O-cahg 'S tells legend about O' • PA *ca:g't6 'old, of old, long ago' - Leer 2008: 35-37.

3. ${ }^{*} \chi^{\mathrm{w}}$ Aq'a 'ferrule' (\#520): Tl $\chi a: G$ 'arrowhead, spear point' - PA *caq' -ḱk '(finger) ring'.

4. * $\chi^{\mathrm{w}} \mathrm{E}$ 'run away, to ruin' (\#522): Tl ka-t-れe 'run away (avoiding responsibility)' - PA *ce:'away, to ruin, forebodingly'.

5. * Хw 'neck, nape'; cį- cirl- cįl- 'head, neck, nape' - PA *ci:N2 'head' - Cf. Leer 2008: 13.

6. * $\chi^{\mathrm{w}} \mathrm{il} \mathrm{Y} \mathrm{V}$ 'pull along, slide' (\#525): Tl $k$-t-ti2t' 'pull along length of sticklike obect' - E -cəX' -ci才' 'S slides, slips' - Leer 2008: 40.

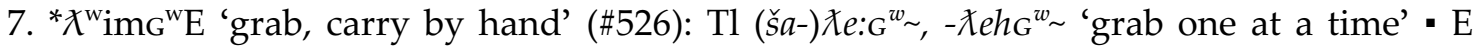
$O$-cihh 'S handles, grabs, carries (quantity of) $\mathrm{O}$ by hand, in handful'; $O-t$-cihh (?) 'S carries (quantity of) $\mathrm{O}$ in hands a long distance' - ? PA *cu:?G, * ${ }^{*}$ G 'stuff inside; crush'.

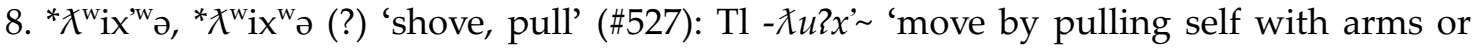
rolling'; Ya-オu2x' (ITl) 'carry obj. clutched to self' - E O-cu:x 'S thrusts O, shoves O (into sth.)'; $O-d-c u: x$ 'S trusts $\mathrm{O}$, shoves $\mathrm{O}$ (into sth.)'; $\mathrm{O}-d l-c u: x$ 'S bastes (in sewing)'; $O-t-c u: x$ 'S moves $\mathrm{O}$ by thrusting with e. g. stick' [with irregular $-x$ instead of $-k$ '] - PA *ce:x́, *cox́ 'stick, poke, shove, thrust, point sticklike or elongated object, body part'.

\section{PND * $\chi^{\prime w}>$ Tl $\chi^{\prime}, E$ E c', PA *'}

Root-initial: 1. “才w'ak'a 'wet' (\#528): Tl d-才’aßk’ 'become wet'47 - E t-c'ak' '(liquid) drips, leaks (by drops)'; ?u:nahd qe?tc'a?k' 'April' (“when water drips down from the trees”) - PA *caḱ' 'leak, be soaking wet'48 - Leer $1992 \# 64 ; 2008$ : 38.

2. * $\chi^{\prime}$ wämGE 'rot, disintegrate' (\#516): Tl $d$ - $\chi^{\prime} u$ ? $\sim$ 'become rotten and smelly, develop sore'; X'uhG 'sore' - E c'ąh 'be extremely soft and flimsy, is disintegrating', etc. - PA *c'วg - $\chi$ 'rot, disintegrate' - Leer 1992 \#61.

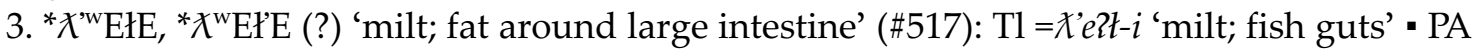
*cəX' 'fat around large intestine of moose'.

4. ${ }^{*} X^{\prime} \mathrm{w} i m X^{\prime w} \mathrm{E}$ 'suck'49 (\#518): Tl $X^{\prime} \mathrm{e}{ }^{\prime}, X^{\prime} e[?] X^{\prime}$ 'suckerfish [Catostomus catostomus]' - E O-c'u2c'-g 'S sucks O (draws O into mouth by suction)', etc. - PA *c'u:nc' 'suck, kiss'.

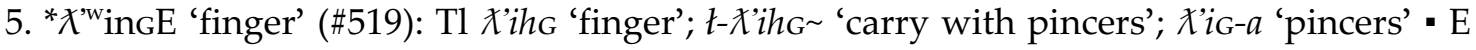
$-y-(t-) c^{\prime} i h_{G}(-t)$ 'fifth (or fourth?) finger'; O-t-c'ịh 'S marks O' - PA *c'əG 'finger, toe' - Leer 2008: 36; cf. Leer $1992 \# 80$.

Root-medial: $1 .{ }^{*} 2 \mathrm{n} \partial X^{\prime w} \mathrm{~V}$ 'soak, be wet' (\#46): $\mathrm{Tl}-n a 2 X$ ' 'become affected by being in water (wrinkle, swell)' - E -2lizc', do-2lizc' 'S is, becomes wet'; lizc' 'dampness'.

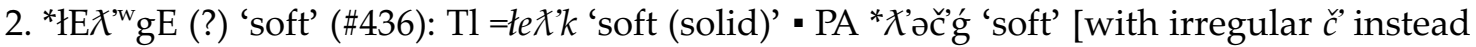
of *c', possibly under the influence of * $2 u:(2) \check{c}^{*}$ ' 'soft'].

3. ${ }^{*} \chi^{\prime} \mathrm{w} i m \chi^{\prime} \mathrm{w} E$ 'suck' - see under root-initial ${ }^{*} \chi^{\prime w}$.

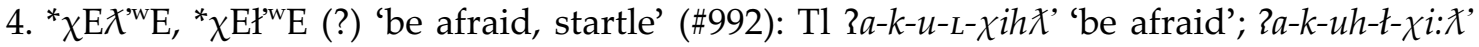
'fear', etc. - PA * $\chi$ e:s, ${ }^{*} \chi \partial \mathrm{s}$ 'start (when startled), be afraid' - Cf. Leer 2008: 19.

\footnotetext{
${ }^{46}$ Also *sa:ǵ under the influence of PA *sa:- 'far, long, distant, ancient', see below on PND *1"ä 'far'.

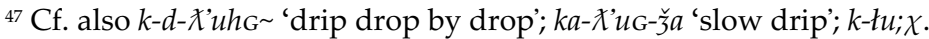

${ }^{48}$ Cf. also some similar, but quite irregular E $t$-cåX' '(liquid) drips, leaks (by drops)' and PA *šoḱk' 'drip'.

${ }^{49}$ Perhaps an expressive reduplicated form of * ${ }^{*}$ 'əwE 'breast, nipple, suck', see below.
} 


\section{PND *1w $>$ Tl 1, E s, PA *s}

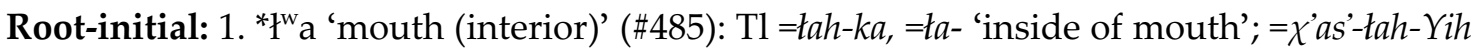
'underneath chin'; $\mathrm{Tl}=\check{s} a-\nmid a-\chi$ ' 'skull' - E sa? [preverb] 'at the mouth'; -sa? 'mouth'; O-sa? [postposition] 'into, to O's mouth'; -sa?-d 'mouth'; $-s a:-q$ '-d 'palate, velum, roof of mouth' - PA *sa:3(-d) 'mouth (interior); tongue; language'; *se:q' 'throat, gullet' [<*sa:(2)-yəq'] - Leer 2008: 34.

2. *łwaq’asgV 'a kind of edible seaweed, dulse’ [Palmaria palmata] (\#486): Tl tahq'asg 'black seaweed, dulse' - E sa:q'sg 'dulse'50.

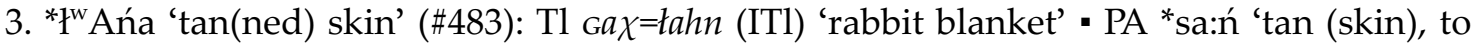
soft (wet hide)'.

4. ${ }^{*}{ }^{\mathrm{w}} \mathrm{Anx} \mathrm{x}^{\mathrm{w} i}$ 'numb, nauseated, hungry' (\#482): Tl (NTl) tà: $x^{w}$ 'famine' - PA *si:nx́ 'numb, tingle, nauseated' - Leer 2008: 9; cf. Leer 2008a \#8.

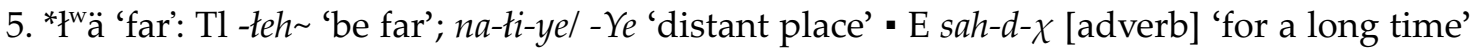
- PA *sa:- 'far, long, distant, ancient'.

6. " ${ }^{\text {ww}} E d E$ 'glide, slide' (\#487): Tl tihd 'throw pl. objects so as to scatter'; -tihd 'slide' - PA *səd 'steer (a boat), soar' - Leer 2008: 35, 39.

7. * ${ }^{\text {w}}$ EmLE 'hollow, hollow object, (plant with) hollow stem' (\#488): Tl tu:t 'fireweed' - PA *su:2nL 'hollow, hollow object' - Leer 1996.

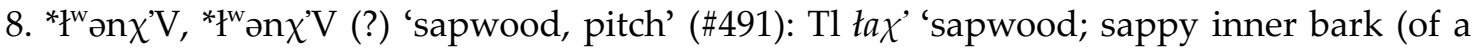
tree)' - E sih $\chi$ 'resin (hardened sap inside grain of wood of any tree)' - Loss of final glottalization in Eyak is irregular.

Root-medial: 1. *dałwa 'heavy' (\#182): Tl -daht , -dat 'be heavy'51 - E t-da:s 'S is heavy'; t-da:s-G [-G 'negative'] 'S is light' - PA *da:3s/*da:s 'heavy'.

2. * Gif $^{\mathrm{w}} \mathrm{V}$, * gif $^{\mathrm{w}} \mathrm{V}$ (?) 'roast on stick' (\#265): $\mathrm{Tl}$ (EN) -Giht 'roast skewered on stick'; L-Giht 'become shriveled from roasting' - E O-gis 'S roasts, warms, burns $\mathrm{O}$ on stick by fire' - The Eyak word-initial velar, disagreeing with the Tlingit uvular, is an inexplicable irregularity - Cf. Leer $1992 \# 152$.

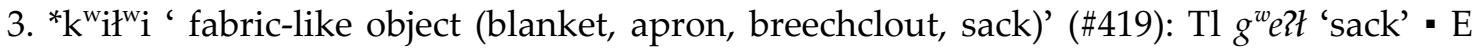
kuhs- $t$ 'breechclout, loincloth; apron (worn at home or e. g. at work in cannery)'; [ $\chi \mathrm{d}$-class] 'fringes'; -ku:l-kuhs-t 'brisket' (and perhaps 'plate, flank') - PA *ḱku:3s 'fabric-like, flat, flexible obj.' - Leer 1992 \#46.

4. * $\chi \mathrm{il}^{\mathrm{w}} \mathrm{E}$ 'pus, semen, viscous matter, foam' (\#1011): Tl š- $\chi$ iht 'to foam'; $\chi$ iht 'foam' [also

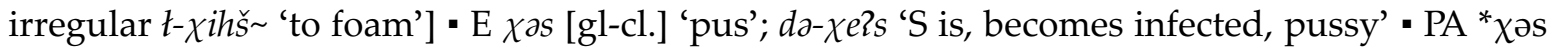
'pus, semen, viscous matter'.

5. * yit $^{\mathrm{w}} \mathrm{V}$ 'a large bird' (\#1094): Tl ye:t 'raven'; šah-ya:t 'hawk' - E yehs 'loon (Gavia sp.)'.

\section{PND *1' ${ }^{*}>$ Tl 1', E c', PA *c'-, s'/s}

Root-initial: $1 .{ }^{*}{ }^{\mathrm{w}} \mathrm{E} \mathrm{s}^{\mathrm{w}} \mathrm{E}$ 'stone' - see above under root-medial ${ }^{*}-\mathrm{s}^{\mathrm{w}}-$.

2. *'w - E c'al, archaic c'al-ih 'bone' (anatomical, not as part of food); -c'al-ih 'bone' (anatomical); -t-c'al-ih ( -c'al) 'bone (anatomical), shell, pit, structural hard part of animal or fruit' - PA *c'on 'bone; leg' - Leer 1992 \#34.

${ }^{50}$ Tsimshian tąask łąask łąqask 'seaweed'; Giktsan łaq'as $x^{w} \sim$ łaras $x^{w}$ 'edible seaweed, sea lettuce' are Tlingit loans. The Giktsan form may have kept the final labialization of Old Tlingit, in this case PND * $1^{w}$ aq'asg ${ }^{w} V$.

${ }^{51}$ Cf. also the antonym $k$-da?s- $k$ ' 'be too light'; see Leer 2008: 30-34 on the alternation $t \sim s$ in Tlingit word derivation. 
3. *'w teat, nipple'; [gl-class] 'milk'; -c'u: (?) 'breast, teat'; O-c'uh 'S (especially infant) sucks O' - PA *c'u: '(woman's) breast; milk'.

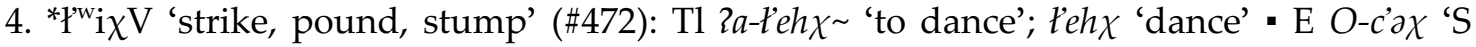
throws, hurls (usually sg.) O'; O-t-c'ax, O-2-(l-)t-c'ax 'pound'; O-d-c'ax 'S throws O'; O-t-c'ax 'S strikes, hits, pounds, breaks O (with held or thrown object)' - Leer 1992 \#196.

5. ${ }^{*}{ }^{\prime w} \mathrm{i} \chi \chi^{\text {'w } E}$ 'move swiftly, spurt' (\#480): Tl $2 a-d-l^{\prime} u\{\chi$ ' 'spray milt, (herring) spawn' - E -c'aq' 'S moves very swiftly through air' - PA *c'əq' 'smoothe, plane, comb O' - Leer 1992 \#179.

Root-medial: 1. *GEY'⿳亠丷厂 'dried (skin, fish)' (\#264): Tl š-Gił' 'become dry and rigid [hide]' - E Gac' 'dry-salmon; some kind of smoked fish; salmon dried, split up the back'; S-t-Gac' 'S makes $\mathrm{O}$ (dry-salmon), S cuts $\mathrm{O}$ (salmon) dry-salmon style' - PA *Ge:(2)s, *Gəs 'king salmon [Oncorhynchus tschawytscha]' - Leer $1992 \# 65$.

2. $\left.{ }^{*} \mathrm{k}^{\mathrm{w}} \mathrm{E}\right\}^{\mathrm{w}} \mathrm{E}$ 'take apart, shed feathers' (\#418): Tl -ke2t’ 'take apart; untie' - PA *kuc' 'molt, shed feathers' - Leer $1992 \# 29$.

3. *wäł'V 'peel' (\#850): Tl k-wuzt' 'peel' - E O-warc'(-g) 'S whips O'; warc'-t, warc'-g-t 'whip'.

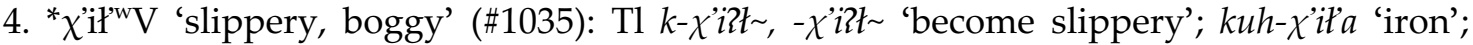
$k u h-\chi$ 'it'- $a=Y e h t$ 'sled'; š- $\chi$ 'izt 'slip'; $k$-š- $\chi$ 'it'-k 'be slippery' - E q'ec' 'slough'.

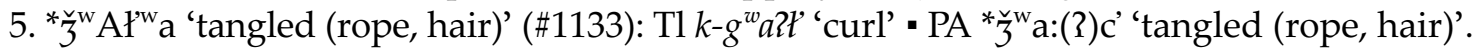

\section{Literature}

Enrico 2004 - John EnRICO. Toward Proto-Na-Dene. Anthropological Linguistics 46, No. 3. P. 229-302.

Krauss 1964 - Michael E. KRAUSS. Proto-Athapaskan-Eyak and the problem of Na-Dene: The phonology. IJAL 30. P. 118-136.

Krauss 1965 - Michael E. KRAUSS. Proto-Athapaskan-Eyak and the problem of Na-Dene II: Morphology. IJAL 31. P. 18-29.

Krauss 1968 - Michael E. KRAUSS. Noun-classification systems in Athapaskan, Eyak, Tlingit and Haida verbs. IJAL 34. P. 194-203.

Krauss 1969 - Michael E. KRAUSS. On the [Classifiers] in the Athapaskan, Eyak, and Tlingit Verb. Indiana University Publications in Anthropology and Linguistics, Memoir 24 of IJAL, Supplement to 35 (4). P. 53-83.

Krauss 1970 - Michael E. KRAUSS. Eyak dictionary \& Indexes. Item EY961K1970b. Ms., Alaska Native Language Archive. Online: http://www.uaf.edu/anla/collections/search/resultDetail.xml?id=EY961K1970b

Krauss 1979 - Michael E. KRAUSS. Athabaskan tone. Item CA961K1978. Ms., Alaska Native Language Archive. Online: http://www.uaf.edu/anla/collections/search/resultDetail.xml?id=CA961K1978

Krauss \& Leer 1981 - Michael E. KRAUSS, Jeff LEER. Athabaskan, Eyak, and Tlingit sonorants. Alaska Native Language Center Research Papers. Number 5. Fairbanks.

Leer 1975 - Jeff LEER. Tlingit stemlist, typed with numerous annotations by the author, including comparanda in Athabaskan and Eyak, making this document valuable for Comparative Athabaskan-Eyak-Tlingit as well. Item TL962L1975m. Ms., Alaska Native Language Archive. Online: http://www.uaf.edu/anla/collections/search/resultDetail.xml?id=TL962L1975m

Leer 1979 - Jeff LeER. Proto-Athabaskan Verb Stem Variation. Part One: Phonology. Fairbanks: Alaska Native Language Center.

Leer 1990 - Jeff LEEER. Tlingit: A portmanteau language family? In: Philip BALDI (ed.), Linguistic change and reconstruction methodology. P. 73-98. Berlin

Leer 1992 - Jeff LeER. March 17, 1992. Na-La-Dene cognate sets. Item CA965L1992b. Ms., Alaska Native Language Archive. Online: http://www.uaf.edu/anla/collections/search/resultDetail.xml?id=CA965L1992b

Leer 1996 - Jeffrey LeER. Comparative Athabaskan Lexicon. Item CA965L1996. Ms., Alaska Native Language Archive. Online: http://www.uaf.edu/anla/collections/ca/cal/

Leer 2008 - Jeffrey LEER. Recent advances in AET comparison. Paper prepared for the Dene-Yeniseian Symposium. Fairbanks, Feb. 26, 2008. Item CA965L2008b. Ms., Alaska Native Language Archive. Online: http://www.uaf.edu/anla/item.xml?id=CA965L2008b. 
Leer 2008a - Jeff LEER. 2008. The palatal series in Athabascan-Eyak-Tlingit, with overview of the basic sound correspondences. In: Kari, James; Potter, Ben. The Dene-Yeniseian Connection. Anthropological Papers of the University of Alaska 5 (new series). P. 168-193.

\section{С. Л. НикОлАЕв. Материалы к реконструкции пра-на-дене.}

Предлагаемая реконструкция пра-на-дене (ПНД) основана на сравнении трех групп языков: 1) диалекты языка тлингит, 2) язык эяк, 3) атабаскские языки (праатабаскский = ПА). Эяк и атабаскские языки близки между собою и восходят к промежуточному праэяк-атабаскскому языку. Регулярные соответствия между эяк и ПА были интепретированы Майклом Крауссом и Джеффри Деером, включая очень сложные соответсвия сонантов. Дж. Деер в своих работах предложил ПНД реконструкцию, привлекательную своей простотой, однако в некоторых отношениях заметно упрощенную. Реальная ситуация представляется нам более сложной. Возможно, это следствие того, что реконструкция Леера основана на приблизительно 300 корнях, тогда как автор использует полный сравнительный корпус, включающий ок. 800 корней. Из соображений объема автору приходится ограничиться лишь кратким обзором своей версии ПНД реконструкции. Сравнительный материал, приводимый в статье, иллюстрирует только ряд сложных звуковых соответствий между передними аффрикатами и спирантами, интерпретация которых отличается от интерпретации Дж. Аира.

Ключевые слова: языки на-дене, атабаскские языки, историческая фонетика. 
